\title{
The Borgo and the Area outside the Walls
}

\subsection{Historical and Archaeological Investigation}

The chapel of St. Catherine's hospice is not extant; in fact, its location, as well as that of the hospice, has been a matter of debate and research to date. According to a document dated April 2oth, 1391, the Italian Hospitaller Domenico de Alamania founded in Rhodes a hospice with a chapel dedicated to St. Catherine, ${ }^{1}$ patron of the langue of Italy since its origins, when the Italian Hospitallers in the Holy Land had undertaken the task of escorting Latin pilgrims to the Sinai Monastery. ${ }^{2} \mathrm{He}$ endowed it with three mills, specifically the 9th, 10th, and 14th mills on the Mole of the Mills, two neighboring houses, two neighboring storerooms, two other storerooms, and other possessions. ${ }^{3}$ Moreover, he designated that the Order's admiral would serve as procurator of both the hospice and its chapel and would be in charge of appointing a person to manage the property of both; the admiral would also designate two chaplains, who would ensure that a daily service was held in the chapel and carried out properly. The donations were confirmed in July 1391 by the Master Juan Fernandez de Heredia. ${ }^{4}$ A few years later, in 1394, the pilgrim Nicola de Martoni confirmed the existence of the ecclesia Sancte Catherine in the town, with many relics in its possession. ${ }^{5}$

The chapel that Nicola de Martoni visited is mentioned again in 1458 in the travel account of the Italian pilgrim Roberto da Sanseverino (1458-1459). He is reported to have attended mass there three times, stating that all pilgrims lodged at this hospice. ${ }^{6}$ Roberto da Sanseverino did not ultimately stay there, but in the auberge of Italy, invited by the admiral. Likewise, Nicolò III d'Este,

1 The Neapolitan Domenico de Alamania was a leading Hospitaller; concerning the duties he was assigned with-Commander of Monopoli, Naples, Avignon, and Cyprus, Governor of Achaia, Lieutenant of the Grand Master in Italy and Rhodes—see Delaville Le Roulx 1913, 190-191.

2 Bacci 2016, 328.

3 Sommi Picenardi 1900, 24; Gabriel 1923, 227-228.

4 Gabriel 1923, 227-228. The document has been published; see Luttrell and O'Malley 2019, 210-213.

5 Piccirillo 2003, 124-126.

6 Cavaglià and Rossebastiano 1999, 118-122. 
whose trip to the Holy Land in 1413 was narrated by Luchino da Campo, stayed with some of his companions at a house with a beautiful garden belonging to Dragonetto Clavelli (mentioned in the source as "Dracone," he was a rich and powerful financier at Rhodes, who served as procurator to the Master and became lord of Nisyros [1401] and Lardos [1402]), ${ }^{7}$ while the rest of the group lodged at the hospice of St. Catherine, also described as very beautiful. ${ }^{8}$ This information differs from Nicola de Martoni's report, which suggests that the hospice was destined to accommodate noble pilgrims. ${ }^{9}$ Indeed, in 1403, when Ruy González de Clavijo arrived at Rhodes with his Spanish embassy to Timur, he stayed at the hospice:

The said lieutenant, and the friars who were with him, when they knew that the ambassadors were approaching, came out to meet them, and told them that the grand master was absent, but that, for the sake of the king of Castille, all their desires should be willingly complied with. The said ambassadors replied that they wished to go on shore, to obtain news respecting Timour Beg, and to collect information. The lieutenant, therefore, ordered them to be lodged in an inn belonging to a knight of the order, in which there was a church dedicated to the blessed St Catherine. The ambassadors went to this lodging on Sunday, August $5^{\text {th }}$, and remained there until Thursday the 3 oth $[\ldots]^{10}$

Additionally, the Castilian traveler Pero Tafur, who passed by Rhodes in 14361437, writes about a hospital other than the Conventual one that was reserved for the pilgrims, where they were provided with everything necessary apart from food. ${ }^{11}$

It seems, then, that the state of the hospice had already been altered by the early 15th century, freely receiving pilgrims of all statuses. This development may have been connected with the effort of Domenico de Alamania around 1411 to transfer the hospice to the jurisdiction of the Franciscans; he received the permission of Antipope John XXIII and of the Franciscan General, but,

7 Delaville Le Roulx 1913, 224, note 1; Tsirpanlis 1991, 331-334; Luttrell 1992b, 218, note 143.

8 Ghinassi 1861, 115, 142-143. Ghinassi read the manuscript in Florence, while Brandoli followed the one in Modena; as a result or perhaps due to erroneous transcription, Brandoli writes diagono (a term she interprets as diaconus deacon], which seems most unlikely) instead of the name of Dragonetto; Brandoli 2011, 47-48, 76 . "[...] in quo hospitali hospitantur omnes peregrini euntes et venientes de Jerusolimis et aliis sacris locis ultra mare in quantumcumque sint nobiles;" Piccirillo 2003, 124.

10 Markham 1859, 17.

11 Pérez Priego 2006, 243; Luttrell 1994, 69-70. 
upon his death between March and June of 1411 the Knights decided not to implement such an action. ${ }^{12}$ It could be that the same reasons that dictated Domenico de Alamania's actions led to the changed management of the hospice by the Order from the early 15 th century on. ${ }^{13}$ The importance of this evolution reflects on the church's status as formulated by the few pilgrims' references; in fact, only Nicola de Martoni reports its rich and impressive collection of relics. It would seem, then, that the church also followed the 15th-century developments; the relics were removed, and the chapel served as the customary place for sojourning pilgrims to attend the liturgy, as in the cases of Roberto da Sanseverino and William III, Landgrave of Thuringia (1461), resulting in a very limited number of references to the site. ${ }^{14}$

The church of St. Catherine, as described in 1522 by the pilgrim Barthélemy de Salignac, had a cemetery with a copy of the Holy Sepulchre. If this was indeed the hospice's church, it seems that at some point it provided burial, most probably for pilgrims who passed away during their stay in the town. ${ }^{15}$

The location of the church has been a matter of research since the early 2oth century. Gabriel identified the hospice of St. Catherine ${ }^{16}$ and was the first to investigate the unidentified monument on Thiseos St. at the southeast of the hospice, which at the time was inhabited by Jewish families, a fact that made it difficult for him to work out a precise plan (Fig. 53). It was a cruciform church with a dome bearing four windows, with an orientation that diverged about $30^{\circ}$ from the east-west axis. ${ }^{17} \mathrm{He}$ could not estimate its date, but expressed his certainty that this monument could not in any case be the hospice's chapel, as it definitely seemed to be a Greek church of humble dimensions.

The edifice collapsed during World War II bombardments and was first excavated during the 1960 ; $^{18}$ in the years $1997^{-2000}$ excavation works were conducted by the 4th Ephorate of Byzantine Antiquities. These, along with

12 Luttrell 1970, 370; Luttrell 1987, 199-200.

13 According to the pilgrims' texts, the hospice would accommodate pilgrims, and it seems that it was sometimes preferred to private lodging: Alessandro di Filippo Rinuccini was offered bed and board by the Italian Knight Marco di Lignano, but he decided to accept only the latter and to sleep at the hospice; Calamai 1993, 76 .

14 Including the ones that refer to the hospice alone; Piccirillo 2003, 124-126; Brandoli 2011, 48-76; Pérez Priego 2006, 243; Cavaglià and Rossebastiano 1999, 118-122; Kohl 1868, 95-96; Calamai 1993, 76; Jacobs 1868, 202-203; von Minckwitz 1856, 89; de Salignac 1593, 148.

15 Although there is no extant evidence in the written sources and the information in the travelogues designates St. Anthony and Our Lady of Victory as burial places for pilgrims; see pp. 165-166 and 186-189 below.

16 Gabriel 1923, 102-106.

17 Idem, 196-197.

18 Kontis 1952, 584-587; Kontis 1953, 275 . 


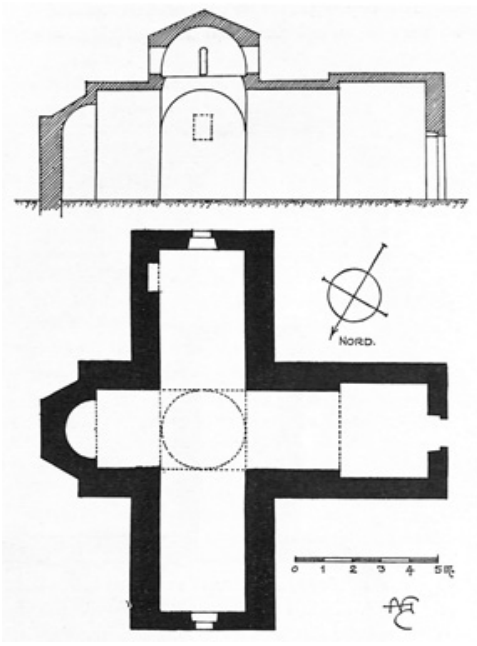

FIGURE 53

Unidentified church on Thiseos St., Rhodes, plan

some consolidation works in 2000-2001, resulted in the present state of the monument and the configuration of the surrounding area (Fig. 54). ${ }^{19}$ According to the archaeological research, the first phase of the building corresponds to an Early Christian three-aisled basilica. At some point it was replaced with a church with a cross plan, from which period evidence for burials within and around the monument survives, dating the use of this adjacent cemetery between the 11th century and the early 14 th. The cruciform church stayed in use until the early 16 th century, as attested by the discovery of 15 th-century coins within its premises. ${ }^{20}$

Only fragments of the pictorial decoration survive, namely in the sanctuary apse, at the intersection of the cross, and in the lower parts of the arms of the cross: on the western and eastern walls of the north arm, and on the northern wall of the west arm..$^{21}$ These have been dated to the 14th-15th centuries. During the 1950s works, in 1952, a dedicatory inscription was discovered on the lower part of the western wall of the north arm, bearing the Greek female

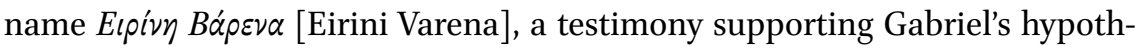
esis on the Orthodox rite of the church. ${ }^{22}$

There is no evidence backing the identification of this anonymous church with the church of St. Catherine's hospice. Even Gabriel's identification of the hospice is now also in question, as the coat of arms he presented as belonging

\footnotetext{
19 Psarre 2007, 467-473.

$20 \quad$ Idem, $467-469$.

21 Idem, 470-471.

22 Kontis $195^{2}, 5^{86-587 .}$
} 


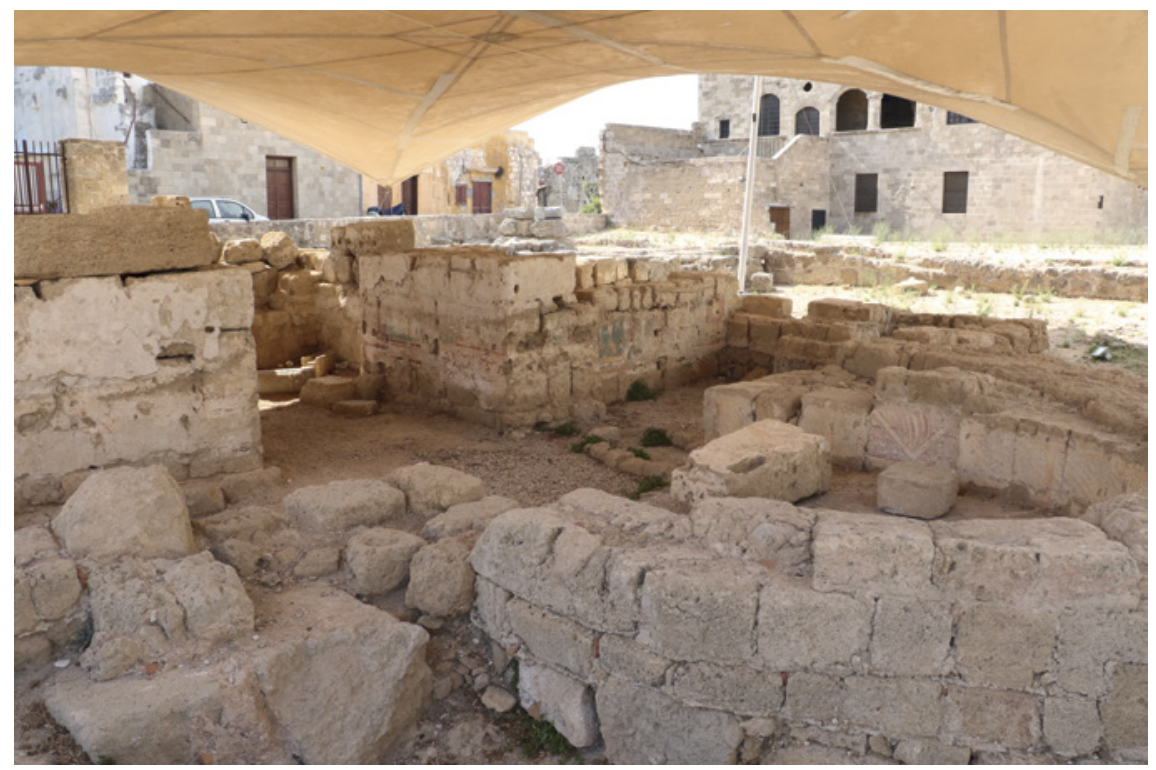

FIGURE 54 Unidentified church on Thiseos St., view from the southeast

to Domenico de Alamania are perhaps dated after 1470 and belong to a different member of the Alamania family, and it is evident that they were placed on the north wall of the building after its reconstruction in $1516 .{ }^{23}$ The edifice has recently been identified with the almshouse of St. Catherine, which was built before 1442 and was administrated by Hector de Alamania, a member of Domenico's family. ${ }^{24}$

In 1856 the French amateur archaeologist Victor Guérin situated the church of Our Lady of Victory at the northeastern end of the walls, an identification that remained prevalent over the following years (Fig. 55) ${ }^{25}$ Some decades later, Gabriel appeared certain; he identified the three-sided apse of the sanctuary and supposed that the indications of rib vaults on the north wall must have belonged to the north aisle; to the south there were traces of a barrel vault and remains of a staircase. Still, the material evidence was limited, and he worked out a hypothetical plan (Fig. $\left.5^{6}\right){ }^{26}$

23 Kasdagli 1994-1995, 224; Manoussou-Ntella and Ntellas 2018, 144; Manoussou-Ntella and Ntellas 2019, 154, 156.

24 Tsirpanlis 1997, 737-740; Manoussou-Ntella and Ntellas 2019, 153-156.

25 Guérin 1856, 141; Kollias 2007, 291-292.

26 Gabriel 1923, 180-182. 


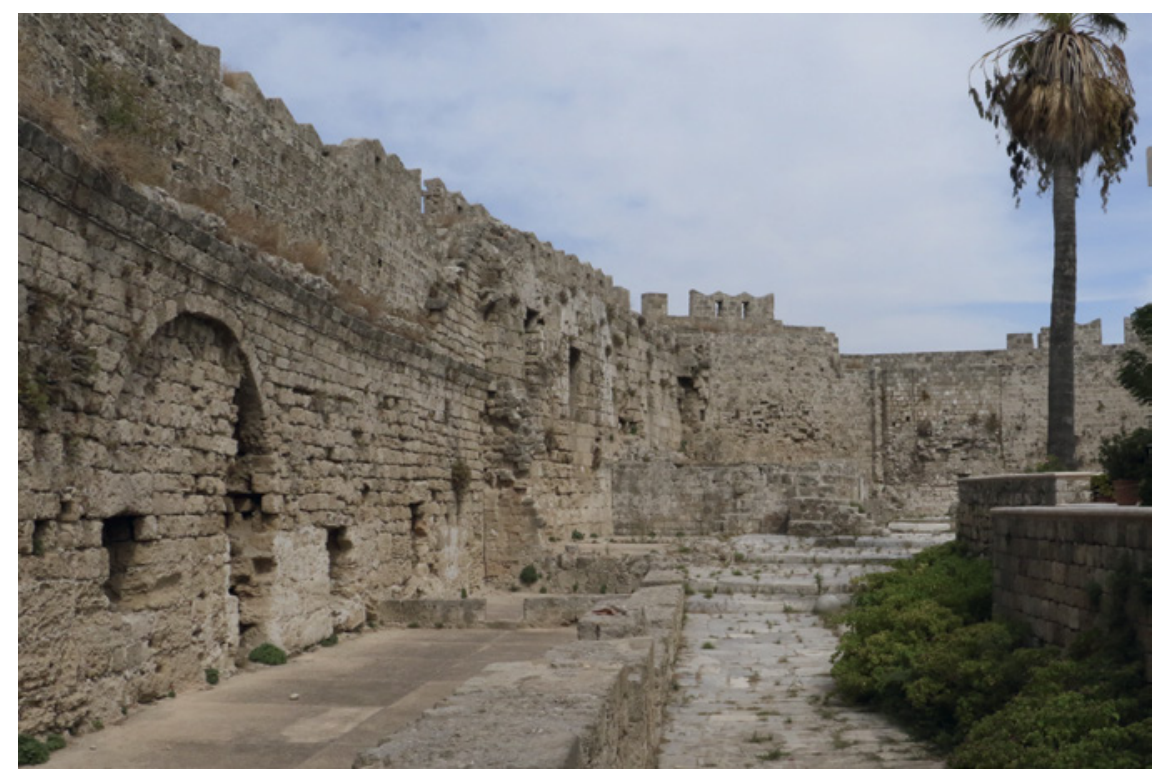

FIGURE 55 Remains of the church formerly identified with Our Lady of Victory, Rhodes

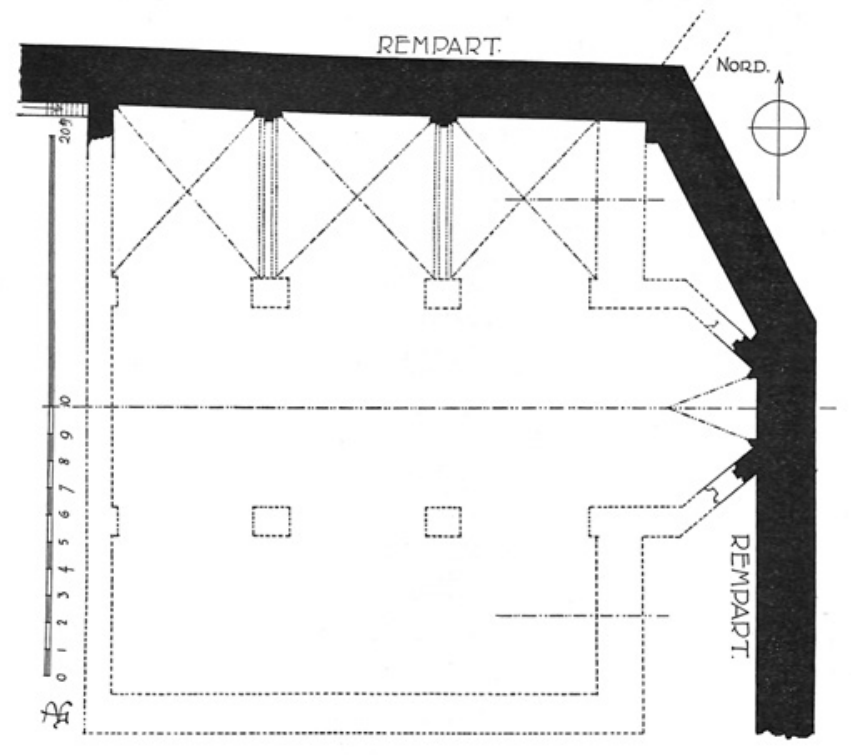

FIGURE 56 The church formerly identified with Our Lady of Victory, Rhodes, plan 

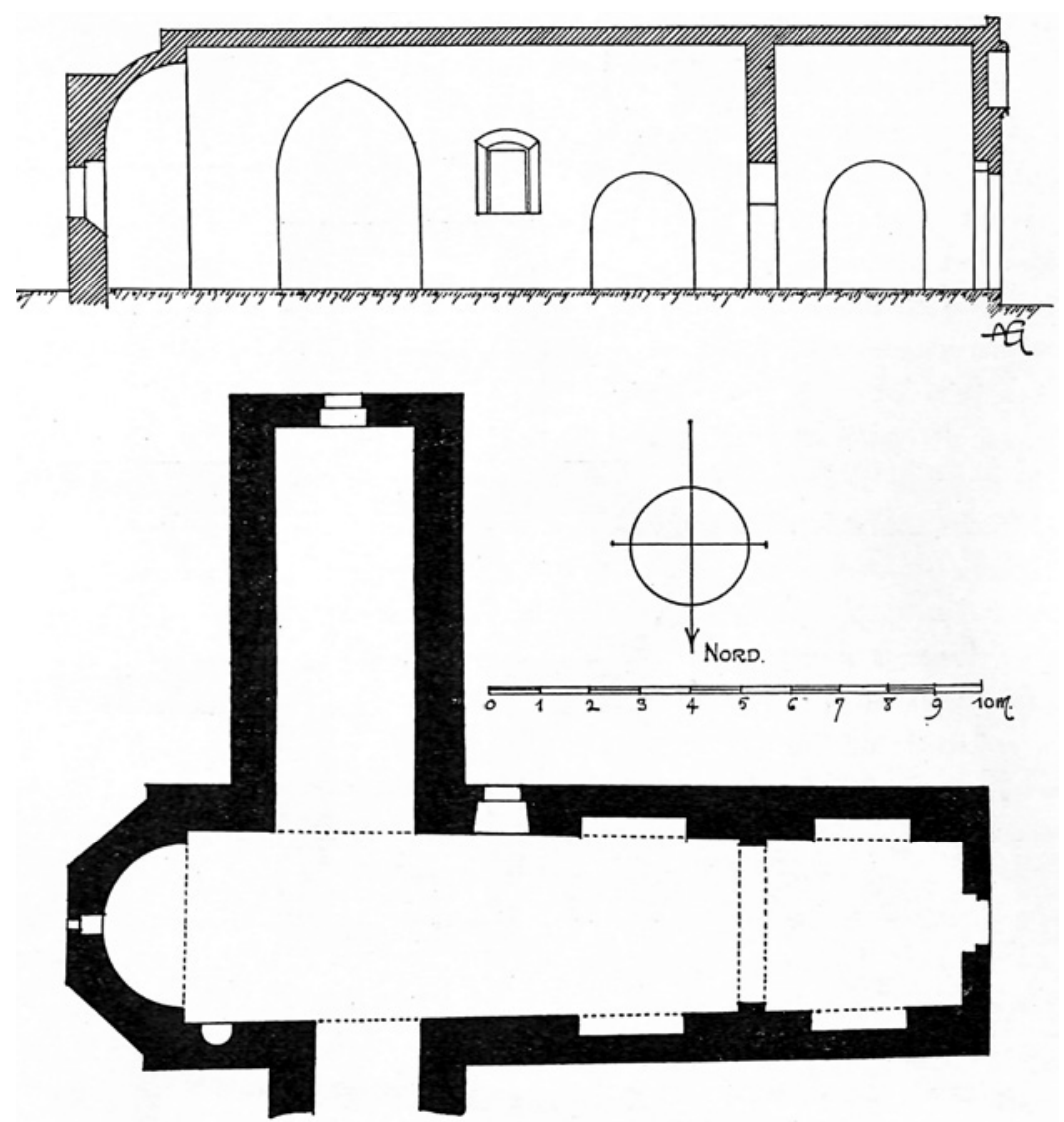

FIGURE 57 The church formerly identified with St. Pantaleon, Rhodes, plan

At the southeastern part, Gabriel identified the Greek church of St. Pantaleon with a nave with a semi-circular apse, which appeared three-sided on the exterior, and a broken barrel vault. ${ }^{27}$ There was a vault at the southern part and traces of another one on the north side, slightly narrower, that indicated a plan with the form of a Latin cross (Fig. 57). The church had a narthex with niches on its lateral sides and similar niches on the nave's walls, while the entrance had been reworked (Fig. 58). The current building, an Orthodox church dedicated to the saint, was renovated in 1948 (Fig. 59).

$27 \quad$ Idem, 197-198. 


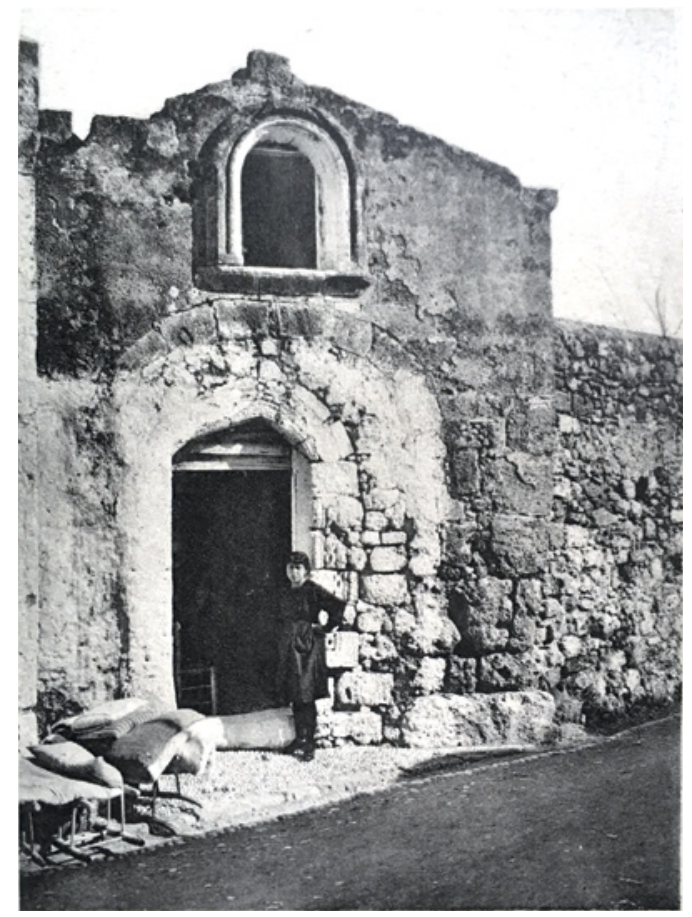

FIGURE 58

The church formerly identified with St. Pantaleon, west entrance

Excavations at the site, from the 1980s onward, uncovered ruins of a singleaisled Gothic church $(7.2 \times 6.1$ meters $)$ with a Gothic ribbed cross-vault and a two-story building adjacent to its western side, with traces of ribbed cross-vaults remaining on the north wall. ${ }^{28}$ On the northeastern side, next to the latter building, a series of cells was uncovered, as well as what seems to be a courtyard paved with ancient luxurious marble stones. A recent investigation has produced a more detailed understanding of the site: a monumental building complex existed to the northeast of the Gate of the Mole, on whose east side the church's hexagonal niche was added before the mid-15th century, when the new walls were built, with Gothic style ribs and pointed arched windows on its lateral sides (Fig. 6o). ${ }^{29}$ This became obvious when investigation of the exterior of the eastern part, at the wall's perimeter, revealed a section of the south side of the apse stuck inside the fortifications (Fig. 61); this - combined with evidence connected with possible coats of arms on the exterior side of this part of the walls that place their dating to the mid-15th century-led to the conclusion that the church in question is earlier than the walls and thus cannot be Our Lady of Victory. ${ }^{30}$

28 Manoussou-Ntella and Ntellas 2008, 115-119; Kollias 2007, 292-293, with bibliography.

29 Manoussou-Ntella and Ntellas 2018, 143-144.

30 Kollias 2007, 292-293, with a detailed examination; Manoussou-Ntella and Ntellas 2019, $145^{-153}$. 


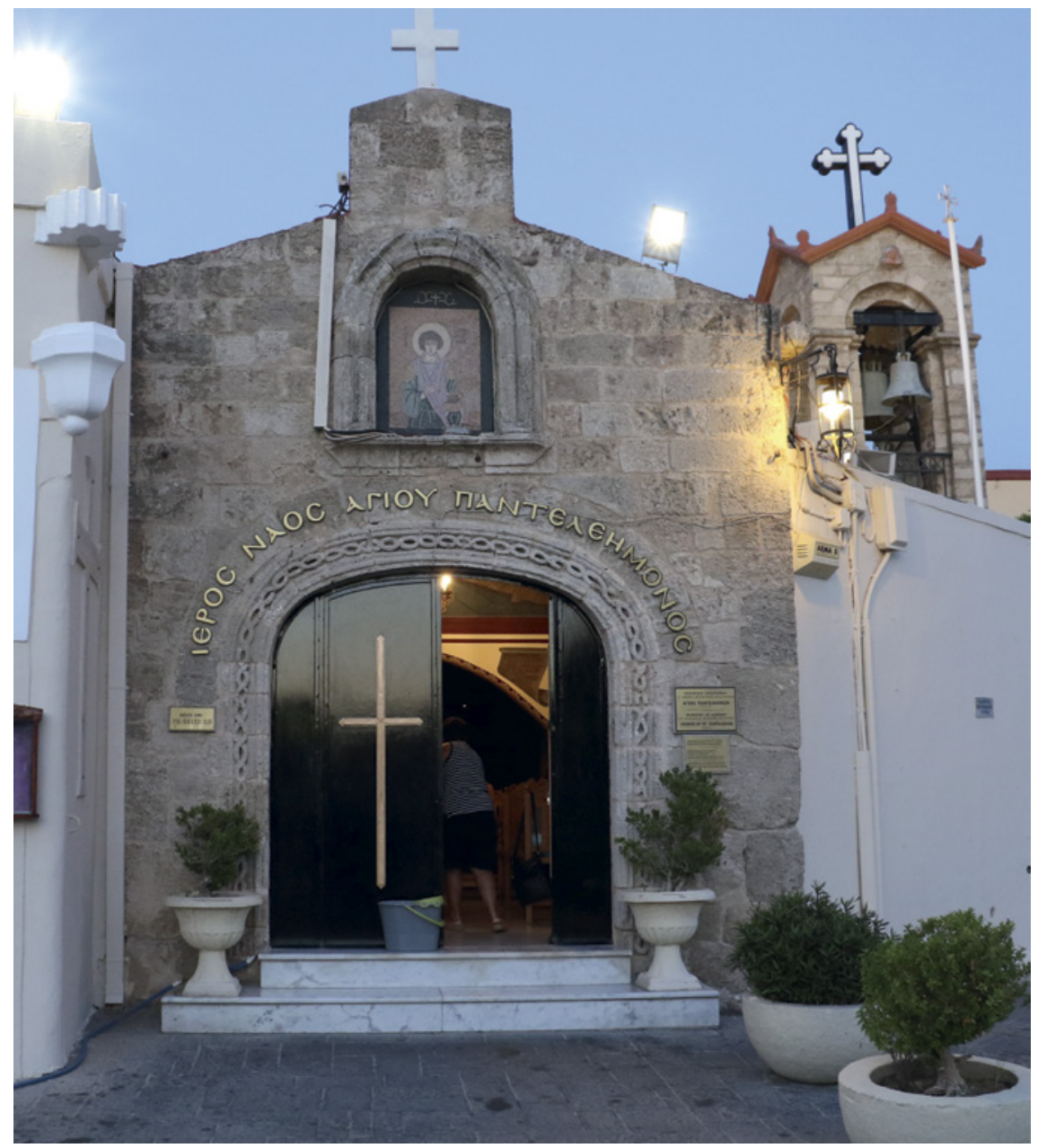

FIGURE 59 St. Pantaleon, west entrance currently

A ceramic tile with Domenico de Alamania's coat of arms found at the site, along with fragments of a tombstone dated 1420-1422, as well as their association with a relief depiction of the Virgin and Child with the arms of Domenico that was discovered next to the walls, reinforced the hypothesis that this may actually have been the location of the hospice and church of St. Catherine; current archaeological research firmly points to this identification. ${ }^{31}$ In that case, this would be the monument referred to as the church of St. Catherine by the Gate of the Mole in $1445,{ }^{32}$ which from 1465 on was referred to as the

31 Manoussou-Ntella and Ntellas 2018, 143-144; Manoussou-Ntella and Ntellas 2019, 145-153.

32 Luttrell 2003b, 289; Maglio 2016a, 156. 


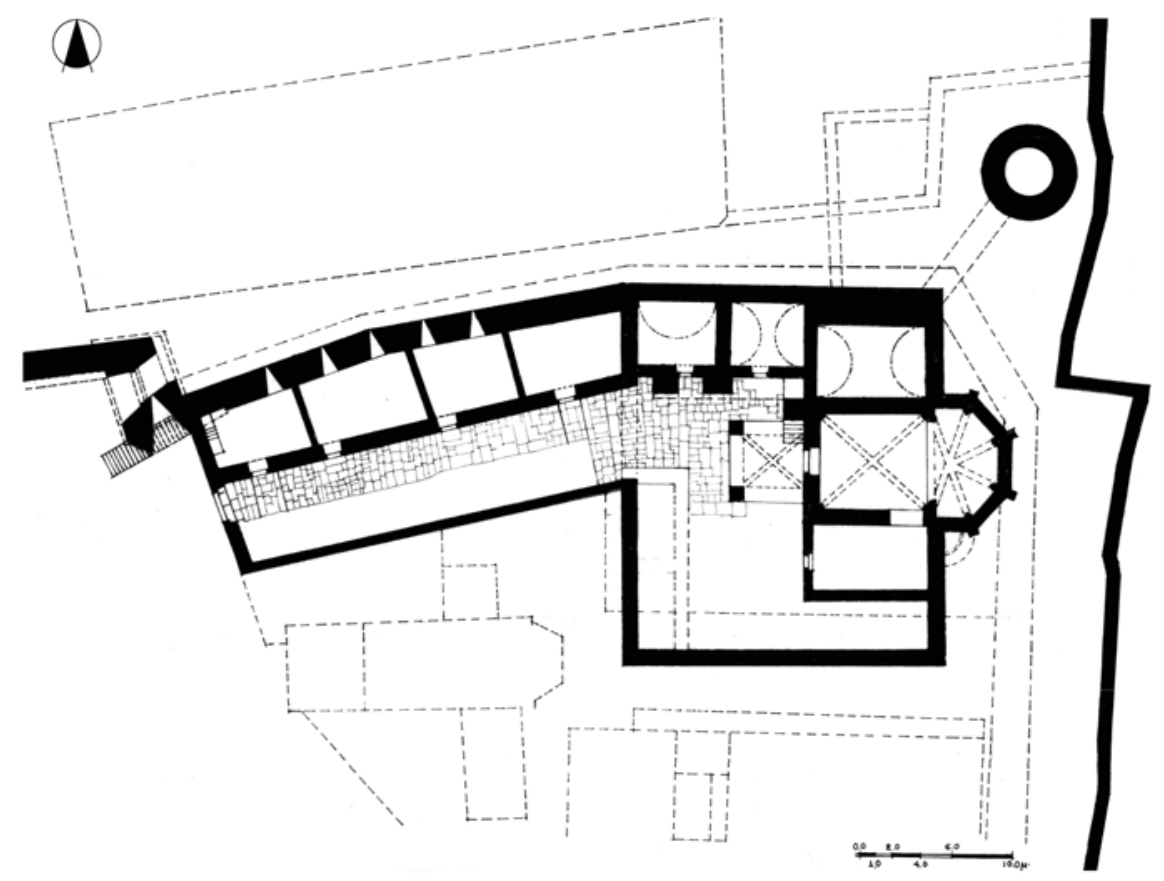

FIGURE 60 Plan of the Hospitaller complex formerly identified with Our Lady of Victory

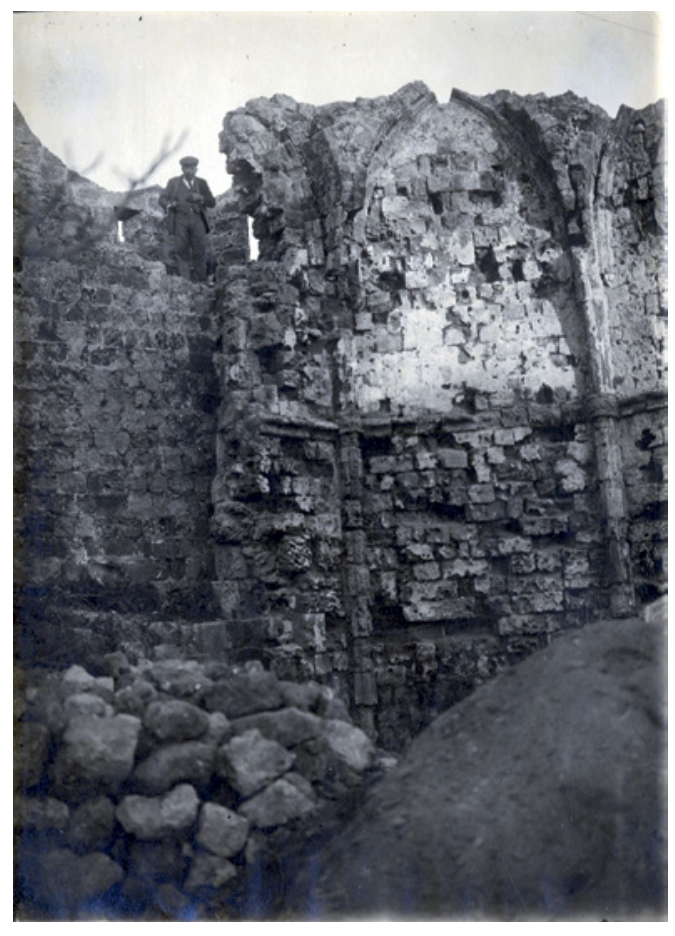

FIGURE 61

Remains of the Gothic apse in contact with the mid-15th-century walls, church formerly identified with Our Lady of Victory, Rhodes 
Gate of St. Catherine, making the identification of the monument even more plausible. ${ }^{33}$ It is certain that future archaeological investigation of the complex, as well as of the southeastern part of the "upper Jewish" quarter, along with the conservation and study of the excavated material of the unidentified church on Thiseos St., will deliver more evidence and bolster further conclusions.

\section{$1.2 \quad$ Cultic Phenomena}

The information concerning the cultic collection kept at St. Catherine derives largely from the travel report of Nicola de Martoni. Apart from enumerating the relics, which takes up most of his text, he gives little, but precise, information about some aspects of the treasures. The collection consisted of Christological, Marian, and saintly relics. ${ }^{34}$

It should be noted that no other pilgrim mentions these relics. Nicola de Martoni asserts that they had been brought to Rhodes by the hospice's donor, Domenico de Alamania, who had received them from the emperor in Constantinople, "qui est suus carus durabilis amicus," taken from the Constantinopolitan churches, where many of them had been placed during Constantine the Great's reign. ${ }^{35}$ This statement sums up the provenance of the relics, and it is known that Emperor Manuel II, in his attempts to recover the Constantinopolitan throne from his nephew, John VII, went to Rhodes for help and was supported in $139 \mathrm{o}$ by two Hospitaller galleys and brethren. ${ }^{36}$ The Knights appear to have aided Manuel financially, as evidenced by a document of 1398 found in the magistral bulls, which lists a series of valuable religious objects that seem to have been pledged as collateral at Rhodes in 1390 and that were returned to the emperor by the prior of France, Renaud de Giresme. ${ }^{37}$

33 Gabriel 1921, 21-22, 62.

34 Piccirillo 2003, 124-126.

35 "Omnes supradictas reliquias dictus dominus noster frater Dominicus habuit in Costantinopoli ab imperatore Costantinopolitano, qui est suus carus durabilis amicus, qui accepit de ecclesiis Constantinopolitanis in quibus multe et pulcre dicuntur esse reliquie et corpora sanctorum et sanctarum a tempore Costantini imperatoris, qui ipsam civitatem Costantinopolis hedificavit et construi fecit in formam et similitudinem civitatis Rome;" ibid.

36 Luttrell 1988, 98-99. Ignatius of Smolensk describes Manuel's attempt to take Constantinople; see Majeska 1984, 102-103. For an overview of Manuel's actions, see Barker 1969, 76-77, with further bibliography. On Manuel's offers of relics in exchange of aid, see Shepard 2012, 82-86.

Loenertz 1958, 226, 231-232, where he publishes the archival source. 
The list enumerates a number of church treasures, with only one of them, a silver coffer with gold bands, containing a relic, one of the True Cross. ${ }^{38}$

Concerning the donation to Domenico de Alamania, as attested by Nicola de Martoni, three groups of sacred objects can be distinguished. Firstly, a group of Christological and Marian relics consisted of a piece of the Holy Sponge, a piece of the reed the sponge had been attached to, a piece of Christ's Purple Robe, and pieces of two of the Virgin's dresses, a red and a purple one. The second group of relics was enclosed in a large jasper reliquary and included a piece of the Seamless Robe of Jesus, a piece of the True Cross, a piece of a finger of the Baptist, and bones of St. Bartholomew, St. Christopher, St. Theodore, and St. Anastasia. Lastly, there was a beautiful icon (cona) with 25 relics embedded in it, bearing inscriptions, of which the traveler was able to identify only some, namely the bones of St. Thomas, St. Prosper, St. Elias, St. Theodore, and St. Marcellinus, some of St. Helena's and St. Agnes' hair, and a piece of the Virgin's veil.

Thus, the Christological relics constituted the core of the collection. The Holy Sponge, the reed on which the sponge had been attached, ${ }^{39}$ relics of the True Cross, the Purple and the Seamless Robes, as well as the Virgin's clothing (her maphorion, robe, and girdle), were relics famously cherished in Constantinople. ${ }^{40}$ Relics of the Baptist's hand were also variously connected with the Byzantine capital, as well as a multitude of relics of saints. St. Theodore's remains had been kept there before being transferred to Venice in the 126os; likewise, St. Anastasia's as well as St. Christopher's relics were present in Constantinople from the late $5^{\text {th }}$ century. ${ }^{41}$

38 "[...] primo uidelicet bussolan unam argenti habentem intus crucem ligni $\langle\mathrm{s}\rangle \mathrm{a}(\mathrm{nc}) \mathrm{ti}$ ueracis et preciosi cum ligamentis aureeis;" ibid. Among the pawned objects there were seven icons, an indication that could further support the hypothesis of Acheimastou-Potamianou that connects two bilateral Constantinopolitan icons from Rhodes with the donations of Manuel II to Domenico de Alamania; see Acheimastou-Potamianou 2009, 199-214.

39 The identity of the cane used to affix the sponge is debatable: the Evangelists wrote about a reed or hyssop, according to the Gospel of John, who was an eyewitness of the Crucifixion; see de Fleury 1870, 270-272.

The presence of the relics in Constantinople is attested to: the scribe Alexandre reported seeing the Purple Robe, the Sponge, and the Reed in 1393, a year before pieces of these Passion relics were seen by Nicola de Martoni at St. Catherine at Rhodes; see Ebersolt 1921, 115-116. On the Christological and Marian relics at Constantinople, see idem, 5-30, 105-140; Bacci 2003, 234-248; Klein 2006, 79-99; Magdalino 2004, 15-30; Majeska 2004, 183-19o; Lidov 2012, 63-91. Various aspects that focus on the relics of Constantinople are discussed in the collection of articles by Wortley 2009 a.

41 Concerning the relics' adventures, see Agathangelos, Maltezou, and Morini 2005, 177-190; Riant 1876-1878, vol. 1, 156-159. For St. Theodore, see AAss, Feb. vol. 2, 22-27; Delehaye 
It could be possible to assume that the first group of relics was also included in a single reliquary, like the other two. ${ }^{42}$ Concerning the second group, placed in a jasper reliquary, no further information is given. ${ }^{43}$ However, the third group, placed in a cona, is considered to have survived, although its identification is rather problematic, as will be examined.

In the Metropolitan Cathedral Museum in Mdina, there is a box-like diptych reliquary with 25 Byzantine steatite reliefs that has been linked with Nicola de Martoni's description (Fig. 62). ${ }^{44}$ This work was described in 1755 by Paciaudi, who also offered an engraving of it (Fig. 63), and it is listed in the 18th-century inventory in Valletta; in both sources it is mentioned as an agiothecium, ${ }^{45}$ while in the 1756 inventory now in Mdina it must correspond to the item mentioned as "una Cassetta fatta a Libro con alcune piancette d'argento entrovi reliquie, e figure alla Greca di diversi Santi."46 The diptych is covered with red velvet bearing five enamel shields, four with the arms of the hospital and one with the arms of the Master Hélion de Villeneuve (1319-1346). The interior consists of 25 steatite reliefs of the following subjects: a homogenous group of 19 plaques with small busts of the Virgin, St. Nicholas, Christ, St. John the Baptist, the Archangel Michael, the Archangel Gabriel, St. John Chrysostom, St. Gregory, St. Paul, St. Basil, St. George, St. Theodore, St. John the Theologian, St. Peter, St. Nicodemus, St. Joseph, St. Anastasia Pharmakolytria, St. Bartholomew, and St. Sabbas; a smaller group consisting of five plaques with St. Onuphrius, St. James

1909, 12-43; Walter 2003. For St. Anastasia, Delehaye 1936, 161; Majeska 1984, 289, with further sources. For St. Christopher, Majeska 1984, 387.

42 The structure of Nicola de Martoni's text suggests this possibility; it was common practice to house different relics in a single reliquary, especially ones that shared some type of link among them, typological or other. See, for example, the aforementioned cross with the relics that the Master Emery d'Amboise received as gifts from the French King Louis XII, see p. 69 above. Other notable cases are the famous Limburg Staurothek, which bears six Passion relics, a relic of the Virgin, and one of the Baptist, and the Stavelot Triptych, with relics of the True Cross, the Holy Sepulchre, and the Virgin; see Hostetler 2012, 7-13; Ševčenko 1994, 289-294; Voelkle 1980; Baert 2004, 80-97.

43 Jasper was a much-valued precious stone: it is mentioned in the Old Testament, but was especially highlighted in the Book of Revelation, with regard to Christ Enthroned and the Heavenly Jerusalem, cf. Apoc. 4.3, 21.11-19. For some hints concerning its perceived qualities and use in the Middle Ages, see Hahn 2012, 41.

44 For the diptych, see Paciaudi 1755, 384-399; Hetherington 2000, 39-55; Kalavrezou-Maxeiner 1985, 18o-184; Luttrell, Buhagiar, and Azzopardi 1989, 45, no. 17; Buhagiar 2009b, 40-41.

45 Paciaudi 1755, 384-399; Valletta, AOM 1953, ff. 104r-v.

46 Mdina, ACM $15 \circ$ A, f. 35 r. This information is also given, but with no specific citation, by Oman 1970, 106. 


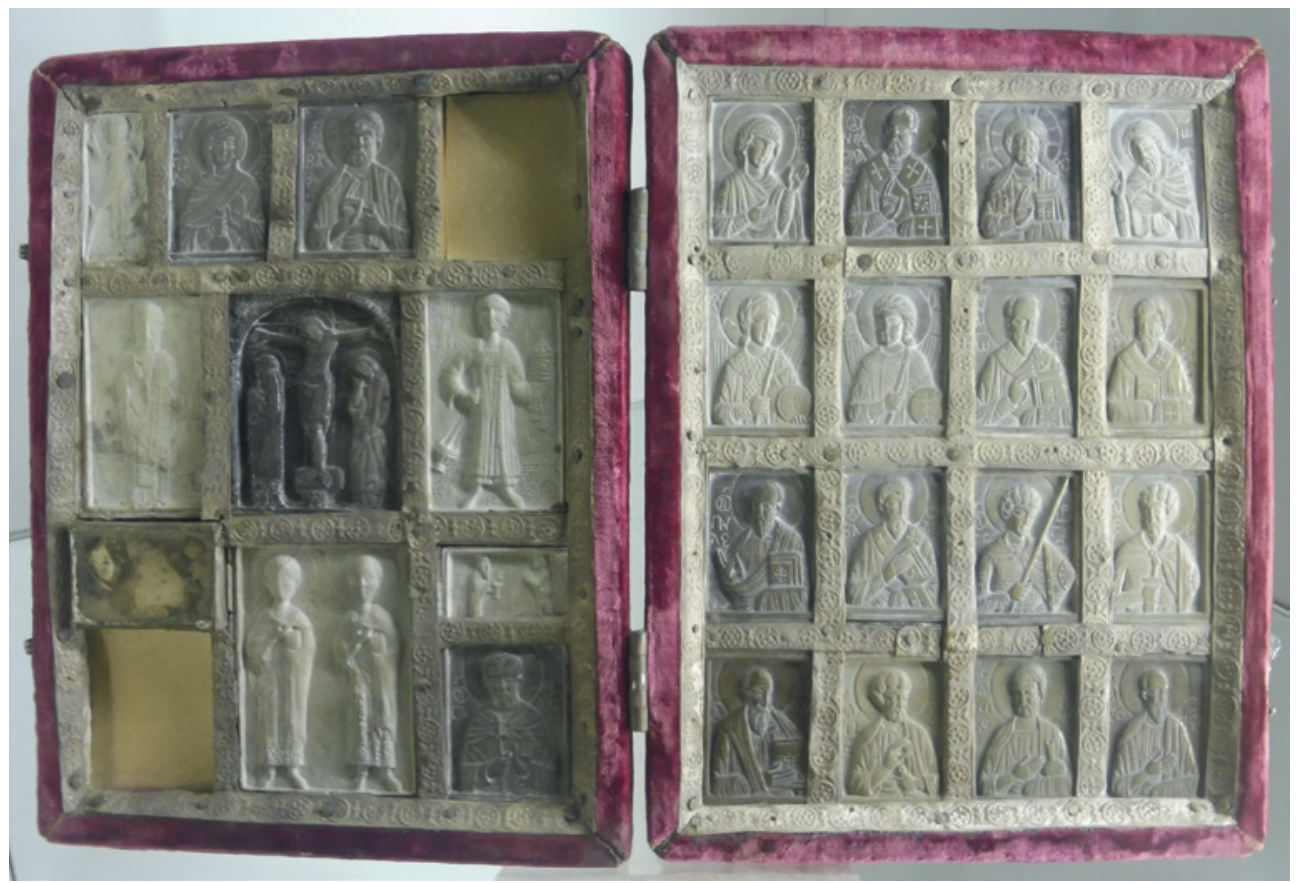

FIGURE 62 Reliquary diptych, Metropolitan Cathedral Museum, Mdina

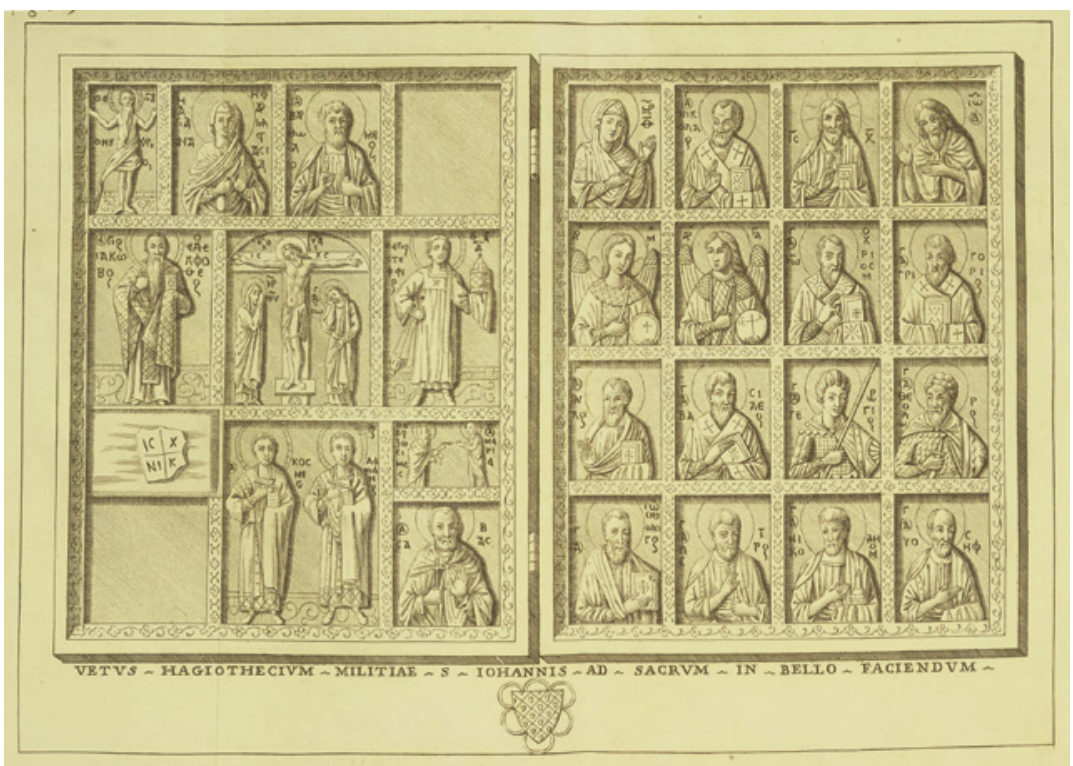

FIGURE 63 Reliquary diptych, 1755, engraving 
Adelphotheos, St. Stephen the Protomartyr, Sts. Cosmas and Damian, and St. Mary of Egypt receiving the sacrament from St. Zosimas; and a plaque depicting the Crucifixion with the Virgin and St. John. ${ }^{47}$ There is also a small rectangular case containing relics, and two empty spaces were probably occupied with other relics or steatite plaques.

The diptych has been linked with Byzantine workmanship of the midPalaeologan era. Its subject matter was deemed to have strong connections with Jerusalem and the Holy Land, due to the presence of St. James Adelphotheos (the first bishop of Jerusalem), St. Mary of Egypt (who converted on the threshold of the Holy Sepulchre), ${ }^{48}$ St. Stephen (who was martyred outside the walls of Jerusalem), and Sts. Nicodemus and Joseph of Arimathea (both protagonists in Christ's Deposition and Entombment); moreover the depictions of St. Anastasia Pharmakolytria and Sts. Cosmas and Damian were interpreted as being related with healing, the core of Hospitaller activity. ${ }^{49}$ As a result, in combination with the stylistic appreciation, it was assumed that the diptych may have been produced in Jerusalem, Acre, or Cyprus before 1346, the date of death of the Master Hélion de Villeneuve. ${ }^{50}$

It has subsequently been discussed that the three groups of steatites, as well as the covering of the diptych, are spoils of earlier works, and the possibility of their assemblage, even in Malta, cannot be ruled out. ${ }^{51}$ This idea was based on the mobility of the plaques, evident in the disruption of the obvious Deesis composition, which must have been formed by the first group of plaques, and on the fact that the nails holding the enamels to the covering do not seem suited to the work. Moreover, the diptych was linked with the second group of

47 The distinction into three groups that is followed here is supported, based on the stylistic appreciation of the work, by Kalavrezou-Maxeiner 1985, 181-184. Hetherington maintains that there are two groups, assuming that the depiction of the Crucifixion belongs to the larger group; Hetherington 2000, 42-43. The interpretation of Kalavrezou-Maxeiner seems more plausible.

48 The depiction of St. Mary receiving the sacrament from St. Zosimas is usually connected with Byzantine sanctuary decoration in relation to the service of the Eucharist; see Gerstel 2006, 152-154, esp. note 76, where five Middle and Late Byzantine examples of the above setting are cited.

49 Hetherington 2000, 44-49. In his hypothesis concerning the connection with Jerusalem, the assumption of Paciaudi-that the relic still preserved in the diptych was one or more stone splinters of the Holy Sepulchre-was further highlighted; nevertheless, the Christological relics were deemed the most sacred of all, and their presence in reliquaries served in any case the intrinsic nature of these objects and cannot necessarily be interpreted as implying a more direct relation with Jerusalem, in terms of production or donorship.

50 Ibid.

$5^{1} \quad$ Kalavrezou-Maxeiner $1985,183^{-184}$. 
relics reported by Nicola de Martoni, assuming that the steatite was mistakenly thought to be jasper. ${ }^{52}$ Indeed, the five saintly relics he mentioned correspond to saints depicted in the steatites, apart from St. Christopher. ${ }^{53}$

Finally, based on a third hypothesis, the diptych has been identified with the cona described by Nicola de Martoni. ${ }^{54}$ This identification also presents problems, because the seven saintly relics he mentions in the cona do not correspond to any saints depicted in the steatites, apart from St. Theodore. On the other hand, the number of steatite plaques corresponds exactly to the number of the cona's relics, and, moreover, the fact that Nicola de Martoni could not decipher most of the inscriptions is well-justified when seeing the diptych, which bears only Greek lettering; ${ }^{55}$ of course, his inability could have been caused by the small dimensions of the work, by inadequate lighting, or even by the limited time he might have spent in front of the reliquary. Besides, he actually writes, "quedam cona multum devota et pulcra, in qua sunt xxv reliquie incluse cum litteris in circuytu;" 56 concerning this beautiful and most devotional icon, he refers only to enclosed relics and not to depictions of the saints, which would point to a work similar to the miraculous reliquary icon at the Monastery of St. John of Rila, Bulgaria, which depicts the Virgin Hodegetria surrounded by small rectangular niches containing relics of 32 saints (all honored by the Church of Constantinople), separated by metallic bands on which their names are engraved (Fig. 64). ${ }^{57}$ His description points to types of work connected with royal and rich donations linked with Constantinople.

$52 \quad$ Ibid.

53 Kalavrezou-Maxeiner, op. cit., proposes that perhaps Nicola de Martoni mistook St. Chrysostom for St. Christopher. In any case, the original composition of saints in unknown, since two compartments are empty. Hetherington dismisses the association with the jasper reliquary, as it would imply that the work has a dating later than Villeneuve's time; Hetherington 2000, 48.

54 Luttrell, Buhagiar, and Azzopardi 1989, 45, no. 17.

55 Luttrell 2003b, 33, esp. note 165 .

56 Piccirillo $2003,126$.

57 The icon at Rila was probably donated to the monastery by the Serbian Princess Mara Branković in the 15th century, although a 12th-century date linked with Manuel I Komnenos is still supported; see Bakalova 2001, 267-270; Bakalova 2005, 193-228. Two known examples of icons with relics, both dated $1367-1384$, are the icon with the Virgin and Child at Meteora and the reliquary diptych in the cathedral of Cuenca, which follows the model of the Meteora icon—-both works share the same donor, Maria Angelina Doukaina Palaiologina; see Talbot 2004, 51-54, nos. 24B and 24C, respectively. Another relevant example is the early 14th-century Constantinopolitan icon with Sts. John Chrysostom, Basil the Great, Nicholas, and Gregory the Theologian, now in the Hermitage Museum in St. Petersburg; see Effenberger 2004, 225-227, no. 134. In these three works, 


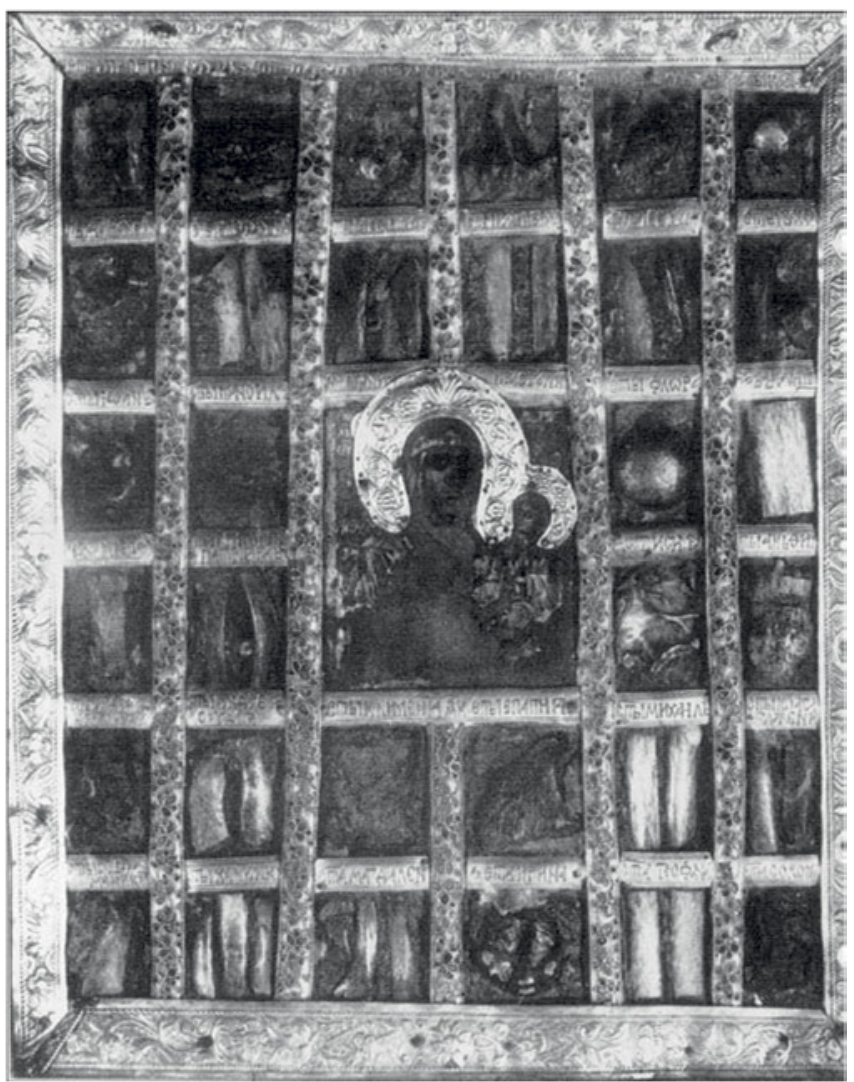

FIGURE 64 Reliquary icon, Monastery of St. John of Rila, Bulgaria

Nevertheless, the present appearance of the Mdina diptych, which has remained the same at least since the 18th century, cannot allow for identification with any of the works mentioned by Nicola de Martoni. Such a present from a Byzantine ruler, bearing this unbalanced and atypical layout, seems highly improbable. ${ }^{58}$

Concerning the three groups of steatites, it seems that the first one, of nineteen 13th-century plaques, seems fit for a reliquary, but does not show

the relics of the saints have been placed around the central icon, as in the case of the icon at Rila, but along with small bust portraits of the saints themselves.

58 Most noteworthy is the disruption of the Deesis scheme on the right wing, where St. Nicholas has been placed between the Virgin and Christ; Hetherington 2000, 42; Kalavrezou-Maxeiner 1985, 181. 
the characteristic traits of Palaeologan art so as to be convincingly connected with the donation from Manuel II. ${ }^{59}$ The second group consists of five late 13th-century plaques, which are worn down in a similar way, use the same decorative background, and present strong stylistic uniformity; it shows a particular choice of saints-St. Onuphrius, Sts. Cosmas and Damien, St. James Adelphotheos, and St. Stephen the Protomartyr (the latter two connected with the Holy Land) — and a smaller plaque with Sts. Mary and Zosimas: the lack of cohesion among these saints points to the possibility that they had been part of a much larger whole. ${ }^{60}$ The Crucifixion, of Palaeologan style, does not seem to be connected with the aforementioned plaques. Bearing in mind the above, there cannot be a convincing argument concerning the identity of the reliquaries found in St. Catherine's church, and it seems, as already mentioned, that these Byzantine treasures were soon to follow a different fate, since no other references are extant; a fact that could imply a private use of the Mdina reliquary, provided it was ever assembled in Rhodes.

Apart from the sacred relics of the church, there is another cultic dimension connected with this space, based on the report of Barthélemy de Salignac (1522). In his narration, he refers to St. Catherine and provides the detail that there was a copy of the Holy Sepulchre in its cemetery. ${ }^{61}$ The presence of such a setting, which would have served as a mimetic evocation of Jerusalem, may have worked on two levels. On the one hand, it would promote the concept of a "surrogate" Sepulchre, extending the properties of the actual one to the travelers who passed away on Rhodes: it could have appeased their anxiety for the salvation of their soul, by "enabling those unlucky travelers who died there without reaching their final goal to be symbolically buried close to the Son of God's life-giving tomb." ${ }^{2}$ On the other hand, it perhaps served as the final stop of a Rhodian Way of the Cross that imitated the one in Jerusalem and, subsequently, established a direct association with the way to Calvary—-the pilgrims' ultimate destination — worked out by the Hospitallers. ${ }^{63}$

\footnotetext{
59 Kalavrezou-Maxeiner $1985,181$.

6o Idem, 182; Hetherington 200o, 47.

61 De Salignac 1593, Dd2. This evidence was discovered and discussed by Bacci 2012, 192. esp. note 41; Bacci 2014, 70-71; Bacci 2017a, 143-144.

62 Bacci 2017a, 143-144.

63 This evidence has been presented and further developed by Bacci; see Bacci 2012, 192; Bacci 2014, 71; Bacci 2016, 327; Bacci 2017a, 143. Concerning the development of the meditation practices connected with the mental evocation of the holy sites, the locative memory, and the kinetic devotion associated with them, see Bacci 2009, 101-110; Bacci 2014, 67-76. Both these articles summarize the current bibliography. Bacci highlights that, apart from the influence of the Franciscan devotional meditation and the Sacri Monti
} 
According to an official document of the Municipality of Fribourg, the chemin de croix of Fribourg was modelled on the measurements that had been established at Rhodes and that were thought to be genuine. Seven Passion pillars were built in 1516 on the initiative of the Hospitaller Commander Pierre d'Englisberg, who had brought with him from Rhodes the exact distances, and were subsequently copied and transferred to Romans-sur-Isère. ${ }^{64}$ Apart from a possible written record with the exact measurements kept by the Order at Rhodes, Pierre d'Englisberg probably copied the existing setting and thus contributed to its dissemination in Western Europe, although the possibility that the accurate distances copied in Fribourg may have originated from a Rhodian written record and not from an actual, exact measuring cannot be ruled out with certainty.

There is some additional evidence in the depictions of Rhodes town from the work of Guillaume Caoursin. In three of the illuminations with a bird'seye view of the town, two Calvary crosses may clearly be seen, one situated near the church of St. Sebastian at the east end of the town's platea ${ }^{65}$ and one at the west end (Figs. 65a, 65b, 65c). ${ }^{66}$ The crosses are also depicted in an $e x$ voto painting that was offered to Notre-Dame in Paris, now at the Hotel de Ville in Épernay (Fig. 66); it was commissioned by Antoine d'Aubusson and Louis XI of France after the victory against the Ottomans in 1480 and essentially propagandized the feats of the Order. ${ }^{67}$ Moreover, a cross is clearly shown in Pinturicchio's portrait of Alberto Aringhieri of ${ }^{1504}$ in the Chapel of the Baptist in Siena Cathedral (Fig. 67) ${ }^{68}$

The present locations of where the crosses were placed must be more or less Ippokratous Square for the former and the hill of the Suleiman Mosque for the latter. ${ }^{69}$ The square was the commercial center of the town, as well as the place of public feasts, celebrations, and events. The execution of the traitor

established in Italy in the late 15th century, the emergence of the Via Crucis, which reproduced the Via Dolorosa, seems to accord with devotional practices in Germany and the Netherlands that integrated the meditation of the Passion with movement analogous to walking along the holy sites of Jerusalem. See also Thurston 1914, 62-75.

64 Text in Kneller 1908, 202-204. See Bacci 2012, 192, note 41; Bacci 2014, 71, note 13, with further bibliography.

65 The square (platea) or market (macellus), like the platea lata to the west, was an unoccupied open space; see Tsirpanlis 1995, 88-89.

66 Gabriel 1921, 12, note 4.

67 Antoine was the brother of the Master Aubusson and had fought with his men at Rhodes during the siege. On the painting, see Hamon 2009, 331-336; Vissière 2009, 337-338.

68 The crosses have been detected by Bacci (forthcoming).

69 Manoussou-Ntella 2013, 118. 


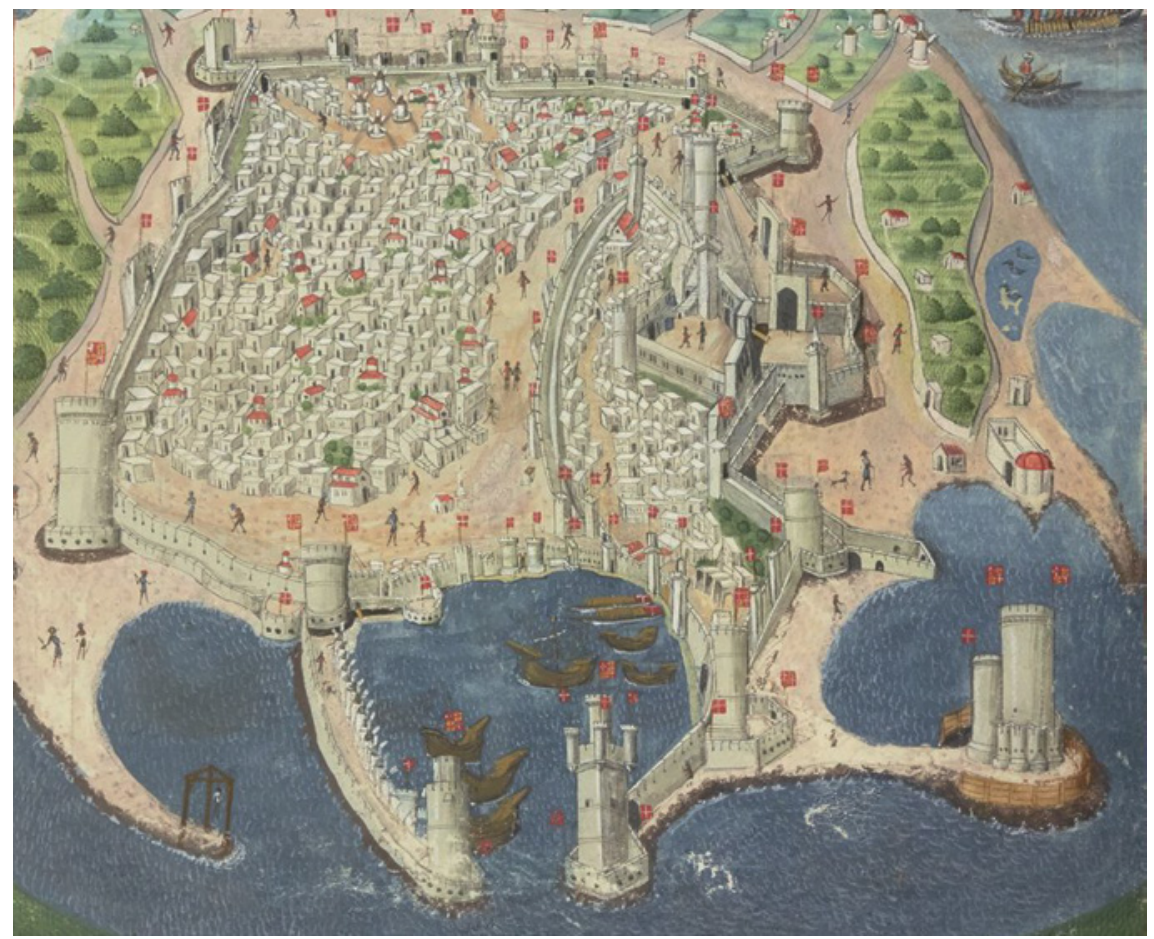

FIGURE 65A Bird's-eye view of the town of Rhodes, ca. 1483. Paris, Ms. Lat. 6o67, f. 18r

and Grand Chancellor of the Order, Andrea d'Amaral, accused of sending information to the enemy during the siege in 1522 , took place next to the cross in the square, mentioned as the croix de la padelle $;^{70}$ the event was depicted in a woodcut on the cover of a rare pamphlet printed in Florence in 1523 (Fig. 68). ${ }^{71}$ Until now, the terminus post quem for the erection of this cross has been ca. 1435, when a chapel dedicated to the Virgin and St. Sebastian is reported to have been erected next to the cross ("in Platea civitatis Colocencis juxta crucem"). It is noteworthy that the chapel of St. Sebastian, next to the croix de la padelle, was built in order for the patron saint to protect the town against the plague, a role that perhaps played some part in the choice of location of the church between the main, Middle Byzantine, city gate and the

70 Ibid. Manoussou Della cites de Bourbon 1527, n.p.; de Vertot 1726, 665. Vatin mistakes the cross at the western part with the croix de la padelle; Vatin 1994, 87.

71 Tsirpanlis $1991,362-363$. 


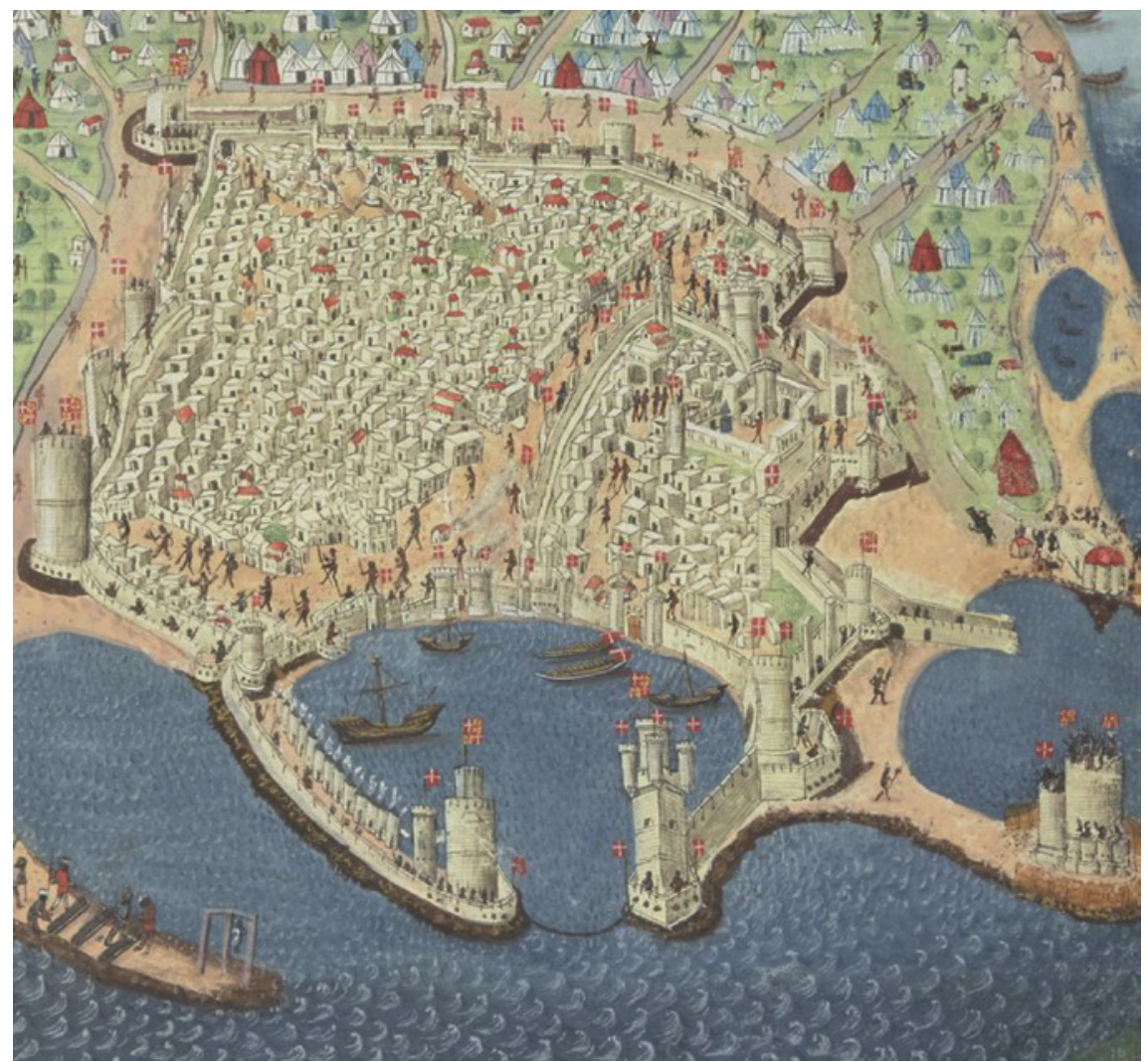

FIGURE 65B Bird's-eye view of the town of Rhodes, ca. 1483. Paris, Ms. Lat. 6o67, f. 32r

commercial area, which was vulnerable to the pestilence. ${ }^{72}$ What is more, in 1446 Pope Eugene IV granted indulgences to everyone who visited and supported this church with a document referring only to Sebastian as the patron saint. ${ }^{73}$ The chapel is clearly visible in the aforementioned illuminations in Caoursin's manuscript. ${ }^{74}$

The hypothesis that the two crosses of the platea may have functioned as stations on a Rhodian Way of the Cross ${ }^{75}$ combines this evidence with the presence of a copy of the Holy Sepulchre and the document from Fribourg. The Calvary, or stepped, crosses have been closely associated with Golgotha and

72 Tsirpanlis 1995, 88-89; Manoussou-Ntella 2013, 138-140.

73 Manoussou-Ntella 2013, 138-140.

74 The location of St. Sebastian seems to have been the one occupied by the Chadrevan Mosque; Gabriel 1921, 12; Gabriel 1923, 116, 211, 231; Tsirpanlis 1995, 92.

75 As pointed out by Bacci (forthcoming). 


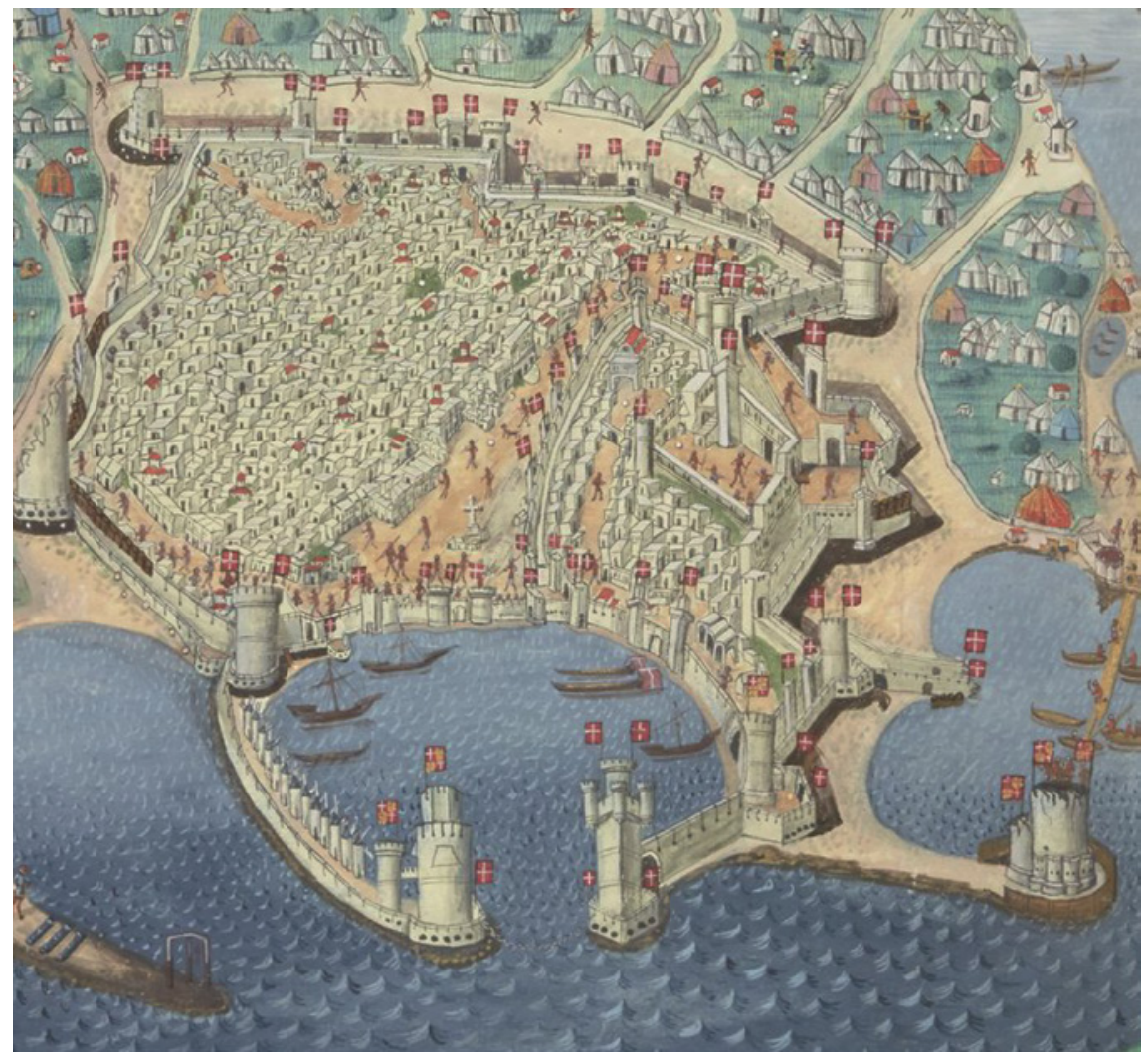

FIGURE 65C Bird's-eye view of the town of Rhodes, ca. 1483. Paris, Ms. Lat. 6o67, f. 37v

the imagery of loca sancta since the late 6th century. ${ }^{76}$ The fact that Caoursin's illuminations depict only two crosses must be related to the visual conventions following the specific medium, given the fact that the open space of the platea easily allowed, in practice, their depiction. This would mean that five more stations should have existed, including the starting point, denominating the praetorium where Jesus was brought before Pilate and condemned to death, and the finishing point, corresponding to the copy of the Holy Sepulchre. ${ }^{77}$ However,

${ }_{7} 6$ The stepped cross seems to be referring to the cross that was erected on Golgotha by Emperor Theodosius, which could be reached by climbing some steps; see Wilkinson 1977 , 177, with primary sources mentioning the steps on pp. 65, 83, 117. They were often depicted on objects associated with the Holy Sepulchre; see, for example, a 7 th-century jug in the Metropolitan Museum of Art in New York and the Monza ampulla no. 4 in Monza Cathedral; Ratliff 2012, 92-93, no. 6o; Grabar 1958, 22, pl. 10.

77 The history of the Way of the Cross is rich and evolved considerably, as indicated by the variety in the number of stations through time and space; see indicatively Thurston 


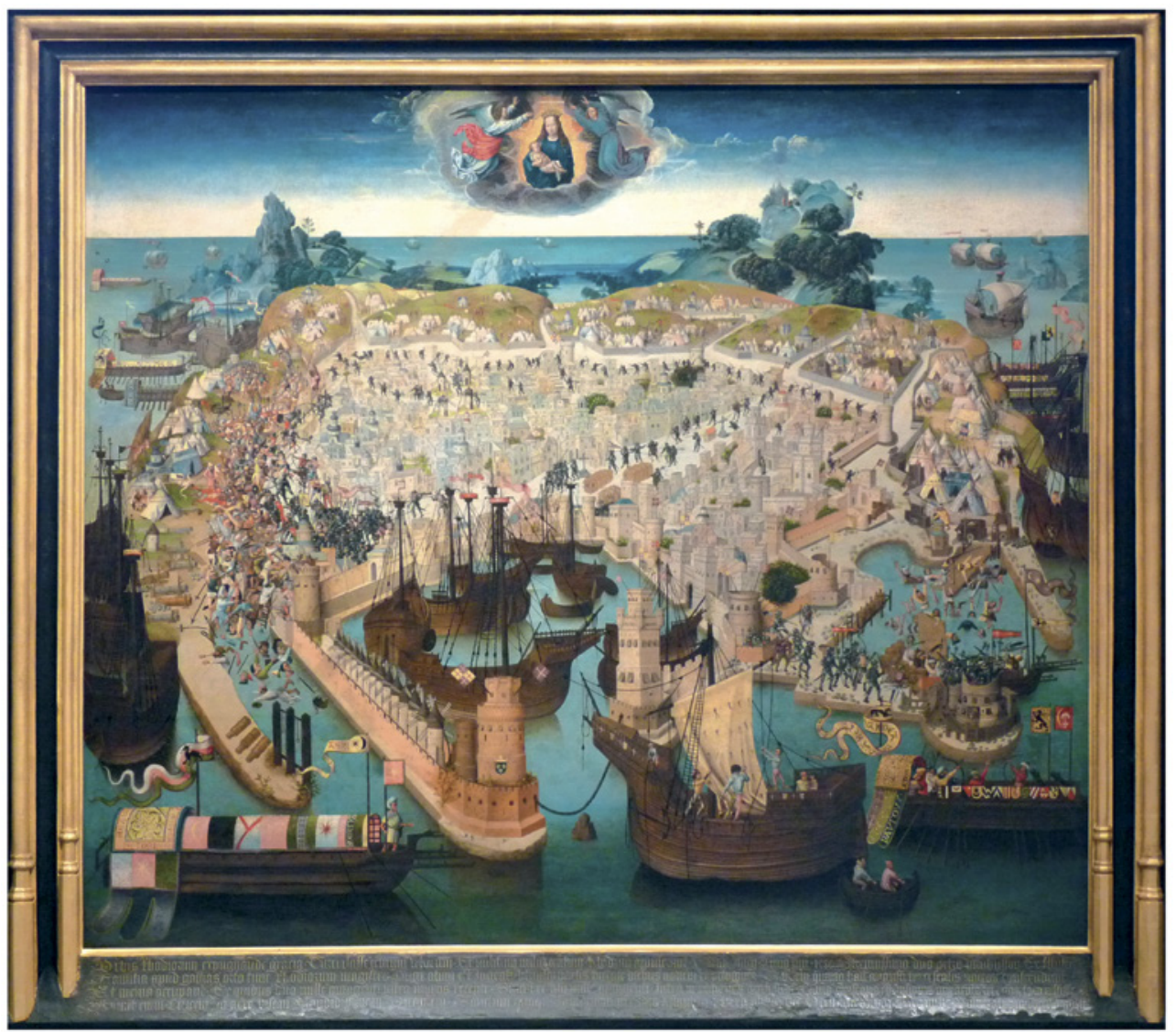

FIGURE 66 The Siege of Rhodes in 148o, late 15th century, oil on panel, Hotel de Ville, Épernay

the evolution of the town's topography after 1522 renders any identification unfeasible; an architectural and technical topographical study would be necessary in order to assess the distances and, in any case, an actual Rhodian Way of the Cross would have conformed to the medieval topography of the town.

With this view in mind, it seems that the church of St. Catherine's hospice, tending to the liturgical and devotional needs of the visiting pilgrims, could be perceived as an extension or, even better, the counterpart of the Order's main

1914; Storme 1973; Kirkland-Ives 2009, 249-270; Lenzi 2016. In present-day Jerusalem, the stations of the Via Dolorosa are fifteen in total, six of them located inside the church of the Holy Sepulchre. 


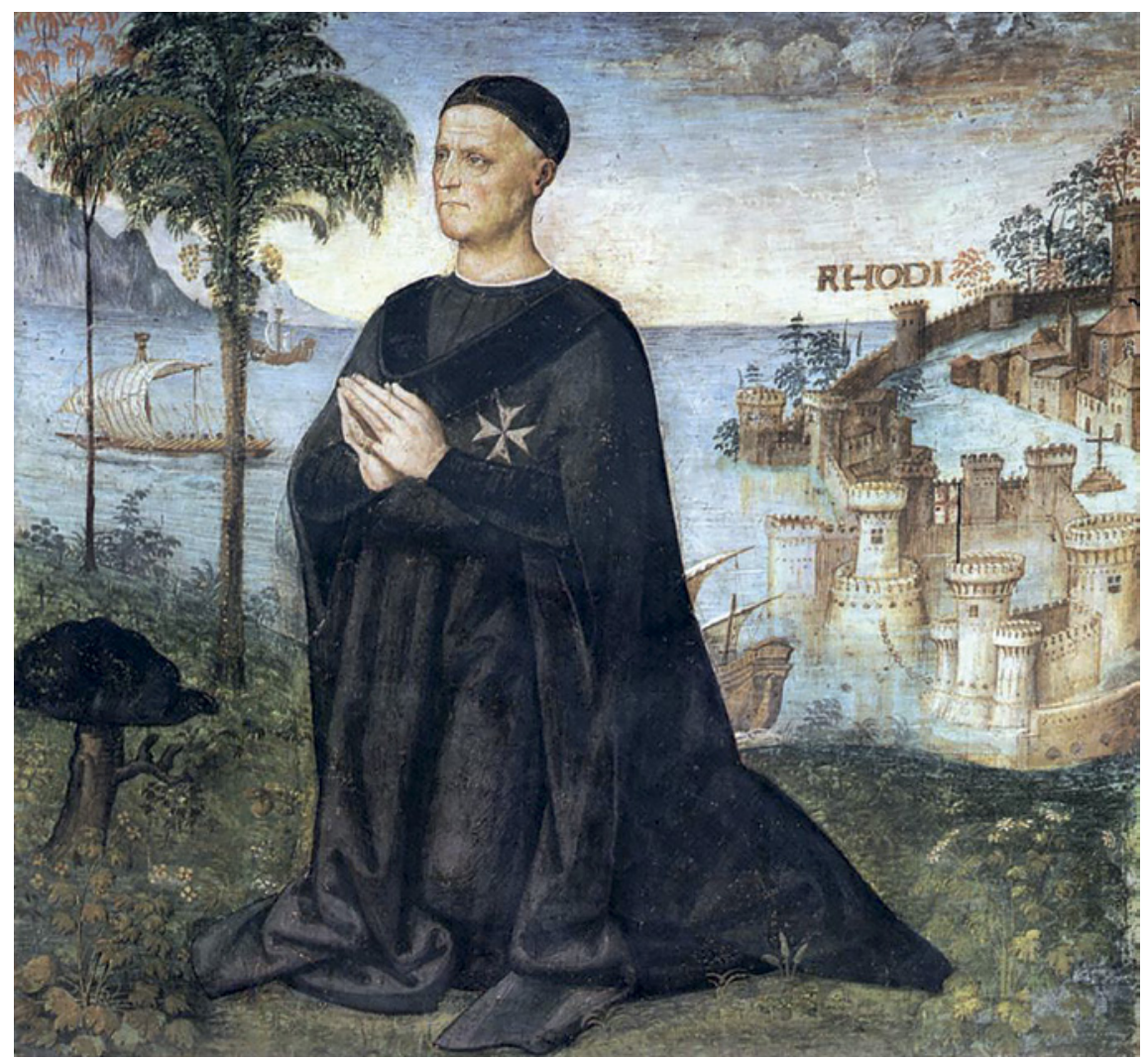

FIGURE 67 Pinturicchio, Alberto Aringhieri, 1504, fresco, Chapel of the Baptist, Siena Cathedral

collection of relics (and, in a way, of the Latin rite at the far east of the borgo), since-as far as is known-St. John of the Collachium, the Grand Master's chapel, and St. Catherine were the only churches housing Christological relics. This conjunction could prove useful when examining whether the copy of the Holy Sepulchre at St. Catherine served as the final station of a Way of the Cross. Nevertheless, information provided by two other pilgrims, the German nobleman Dietrich von Schachten (1491), that a copy of the Holy Sepulchre was found at the church of Our Lady of Victory, which had been granted to the Franciscans, and the wealthy merchant from Valenciennes Jehan de Tournai (1488-1489), who situates it at the Augustinian cloister, opens new possibilities, which will be investigated below. Whatever the case, the function of the church as the eastern topographical counterpart of the Order's cultic collection is evident. 


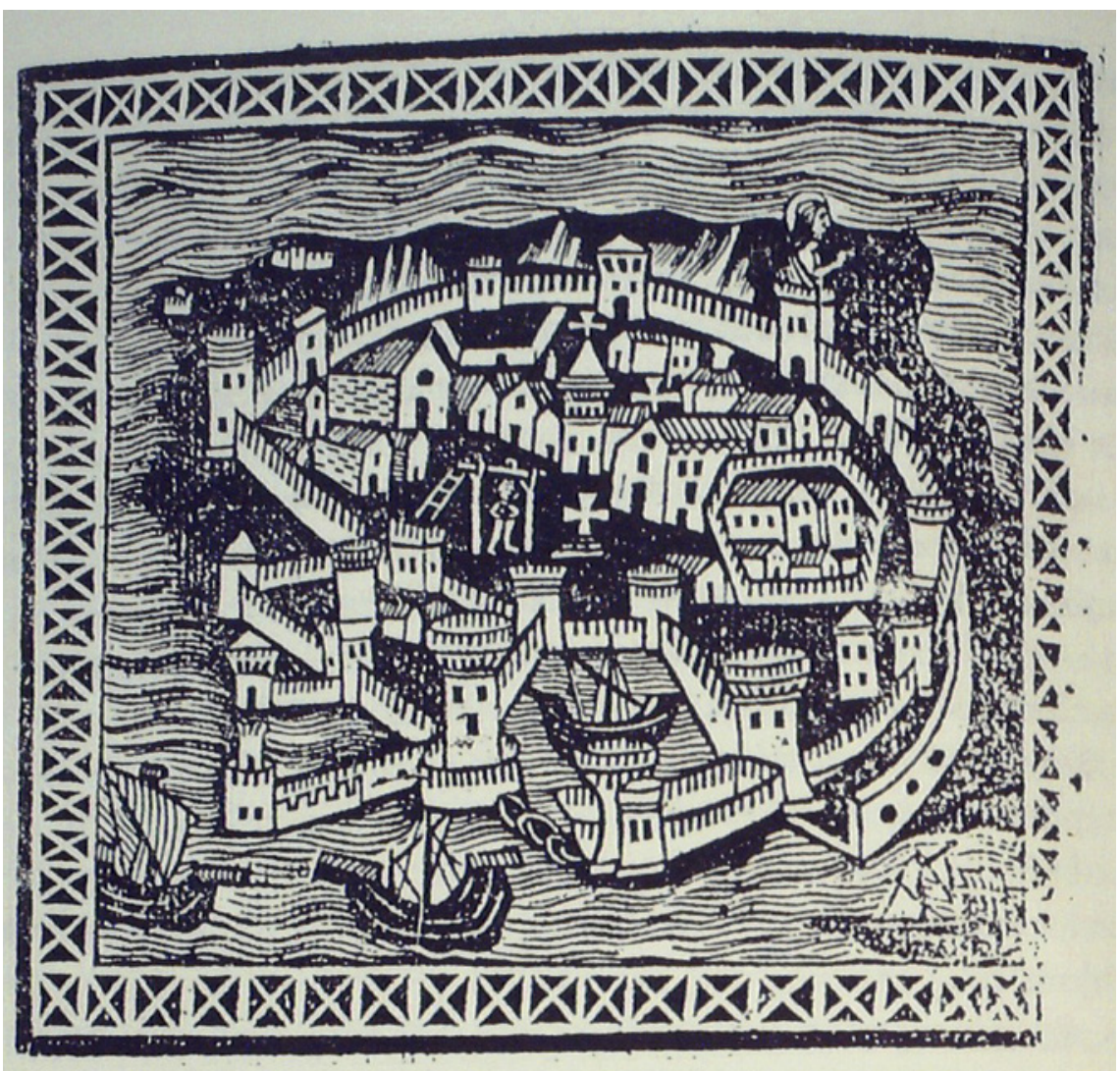

FIGURE 68 The town of Rhodes, 1523, woodcut

2

\section{St. Anthony}

\subsection{Historical and Archaeological Investigation}

The church of St. Anthony was situated outside the walls of Rhodes town, in the western part of the port of Mandraki, opposite St. Nicholas' tower. Around the church lay the cemetery of the Knights, where many of the tomb slabs now in the Archaeological Museum of Rhodes were discovered. ${ }^{78}$ It occupied approximately the present-day area of the Mosque of Murad Reis and its cemetery. ${ }^{79}$

78 Gabriel 1921, 14-15; Gabriel 1923, 211, 214; Luttrell 2003b, 47.

79 Manoussou-Ntella 2012b, 26. 
According to a version of The Chronicle of the Deceased Masters elaborated in $1367-1383$, the church was built by the Master Villeneuve (1319-1346);80 it is attested, though, that it already existed in 1314, when it was designated that it should belong, along with its income, to the Prior of the Convent. ${ }^{81}$ Villeneuve's contribution was perhaps restricted to the erection of a chapel at the already existing church, as in a later version of the Chronicle, dated 1467-1476, he appears to have chosen the cemetery of St. Anthony as his burial place and to have endowed it with a chapel; this decision was connected with an attested miracle there, though he later decided to build his funerary chapel in the Conventual church. ${ }^{82}$

In May 1480, when it was certain that there would be an Ottoman assault on Rhodes, it was decided to destroy the church for defense reasons. ${ }^{83}$ The site was used during the siege by the Ottomans, who launched from its environs cannon attacks against St. Nicholas' tower. ${ }^{84}$ After the siege, it was quickly deliberated, on September 11th, 1480, that St. Anthony should be completely destroyed, so as to protect the tower of St. Nicholas in a future attack, apart from a side chapel that would be used for the mass for the dead; if an imminent threat were to arise, the chapel would also be demolished, and the masses would be celebrated in other churches. The Order was to rebuild the edifice when peaceful days would come, so that the memory of the departed should not perish. ${ }^{85}$ It seems that it was soon decided to destroy the chapel as well. ${ }^{86}$ These deliberations do not appear to have been implemented immediately; according to the decision of February 3rd, 1481, 19 Greek and Latin churches around the town, among which was St. Anthony, would be demolished, so as not to provide the enemy with shelter for impending military attacks. In the case of St. Anthony, the mill that was nearby was also destroyed. ${ }^{87}$ Why would there be different deliberations before and after the siege? Bearing in mind the arrival

\footnotetext{
8o Text in Luttrell 2003b, 187-191.

81 Idem, 174-175.

82 Idem, 183.

83 Bosio 163o, 399. Gabriel publishes a deliberation in the Libri Conciliorum, dated May 21st, 1480, to demolish "ecclesia S. Anthonij et beate Marie lemonitre et alia loca que impediunt;" Gabriel 1923, 211.

84 Gabriel 1923, 63, based on the information given by Caoursin in Obsidionis Rhodie Urbis descriptio. Bernhard von Breydenbach provides the information that the Ottomans installed three cannons in the garden of St. Anthony, where they also cut the trees, as well as describing their artillery in the western part of the garden; Mozer 2010, 694-695. See also Bosio 1630, 399ff; Setton 1978, 351-353.

85 Setton 1978,361 , esp. note 45 .

86 Bosio 1630, 429.

87 Idem, 431-432.
} 
of the Ottoman troops on May 23rd, 1480, it seems doubtful that there would have been time to implement the decree of 1480 , which would explain why it was put into action afterward. ${ }^{88}$ It was some months later, in October 1481 , that the Master Aubusson decided to reconstruct St. Anthony and to build a more sumptuous building than the previous one, as well as a larger cemetery, since it was supposed that, after the death of Mehmed the Conqueror and the following conflicts over the throne between his sons, Bayezid II and Djem, the island would enjoy a time of peace. ${ }^{89}$

As reported by Nicola de Martoni, the cemetery was used for the burials of the brothers of the Order in the 14 th century. ${ }^{90} \mathrm{He}$ explains that the most noble brethren were usually buried in the Conventual church, but also at St. Anthony, according to each person's will; at some point the choice of the latter cemetery was more desirable, because of the absolution a pena et a culpa that was granted to it. Pilgrims would also find their ultimate resting place at St. Anthony. Hermann von Wartensleben, one of the pilgrims in the group traveling with Dietrich von Schachten, died on the return trip from the Holy Land on October 9th, 1491, and was buried at St. Anthony; this was also the case for Christoph von Bayern, who died on August 15th, 1493, as reported by Heinrich von Zedlitz (1493), Wolfgang Zillenhart (1495) — who adds that many other pilgrims lie there, Alexander, Count Palatine of Zweibrucken (1495), Peter Rindfleisch (1496), Arnold von Harff (1497), and Bernhard von Hirschfeld (1517). ${ }^{91}$

The information that can be deduced concerning the material aspects of the church derives from a few pilgrims' reports and some depictions of the town, mainly from the 15th and 16th centuries. Nicola de Martoni is again the one who provides the most detailed report on the site, describing a vaulted church and a large courtyard with $5^{1}$ arched tombs along its perimeter, which

88 To support this hypothesis, it would be interesting to note the differences among the manuscript illuminations of Caoursin ca. 1483, Paris, Ms. Lat. 6o67, ff. 18r, 30v, 32r, 37v, $48 \mathrm{v}$. These depictions of the town and of the port of Mandraki, chronologically sequenced in different stages of the siege, provide two versions of the building: one where it appears standing fully (in the first three illuminations), and one where it is ruined (in the latter two).

89 The decision was taken on October 25th, 1481; see Gabriel 1923, 211; Bosio 1630, 435. The pilgrim Dietrich von Schachten (1491) also attests the reconstruction by Aubusson, and Arnold von Harff (1497) adds that the church was small (kleyn); Röhricht and Meisner 188ob, 217; von Groote 186o, 71.

$90 \quad$ "[... ] in quibus non seppelliuntur nisi fratres dicti ordinis;" Piccirillo 2003, 26.

91 Röhricht and Meisner 188oa, 297-298; Röhricht and Meisner 188ob, 216-217; Reinhold Röhricht 1894, 289-29o; Gebele 1932-1933, 114; Karbach 1997, 91; Röhricht and Meisner 188oc, 340; von Groote 186o, 71; von Minckwitz 1856, 101-102. 


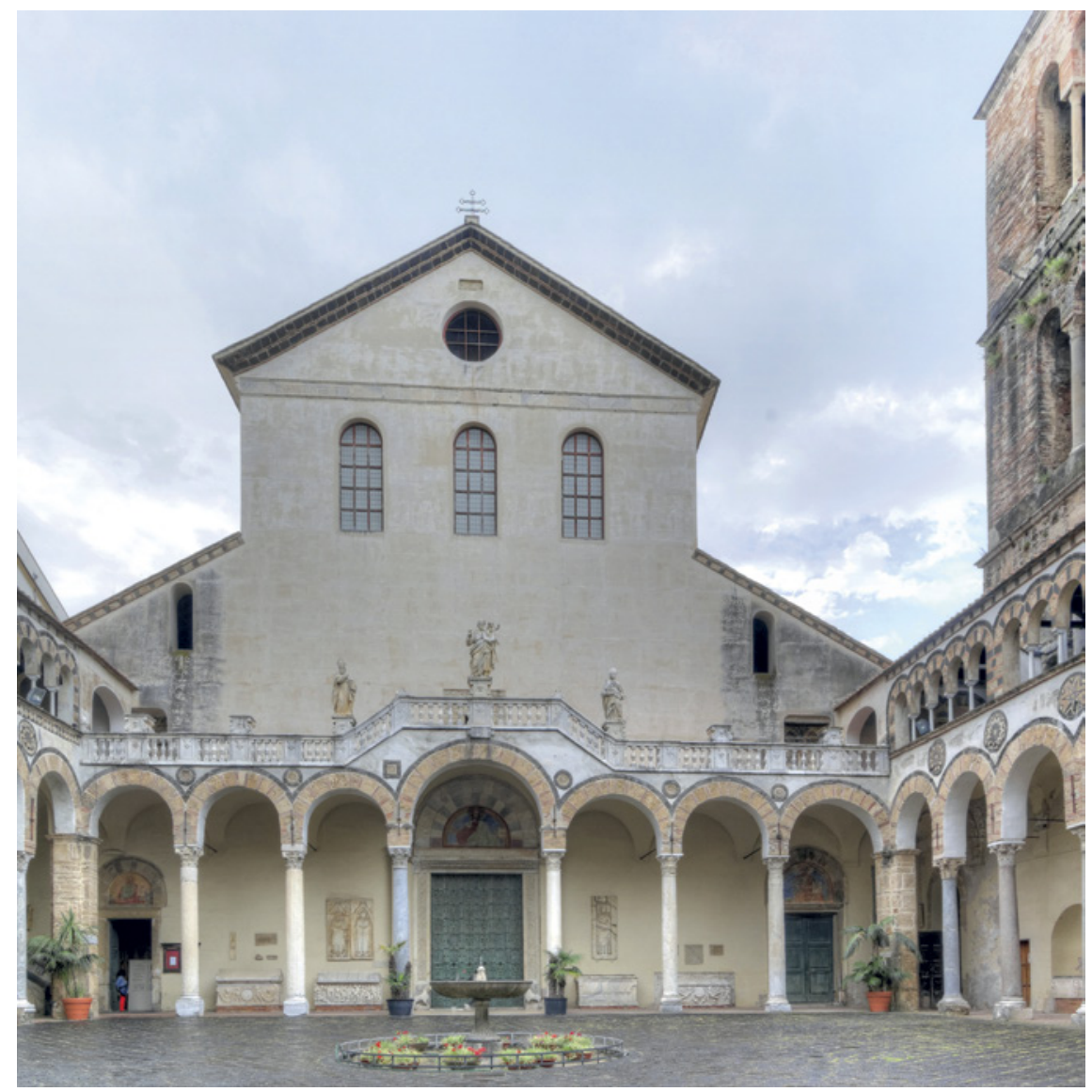

FIGURE 69 Salerno Cathedral, view from the west

he compares to the church of San Matteo in his native Carinola. ${ }^{92}$ It is possible that he was hinting at the Romanesque cathedral of Salerno dedicated to St. Matthew and specifically to its characteristic, vast atrium surrounded by a gallery with semicircular arches resting on 28 granite columns and four corner pillars (Fig. 69).${ }^{93}$ Concerning the dimensions of the church before 1481, it must have been small, since it would be rather contradictory to think that

92 "Extra civitatem, est ecclesia Sancti Antonii subdita dicto ordini Sancti Johannis, constructa ad lamiam, cum magno cortilio, quasi unius modii, clauso ad portam. Et in circuytu muri dicti cortilii, sunt LI sepulture ad arcus et lamias sicut sunt ille de Sancto Matheo de Caleno, in quibus non seppelliuntur nisi fratres dicti ordinis;" Piccirillo 2003, 26. Luttrell estimates that the courtyard would have measured approximately $35 \times 35$ meters; Luttrell 2001, 142.

De Onofrio and Pace 1981, 269-289. 
the lavish building by Aubusson would have been smaller than the previously existing one. ${ }^{94}$

The surviving depictions in late medieval maps are generally not reliable in their schematic depictions; in some cases, though, they prove to be quite useful in the quest for clues concerning the materiality of the edifice. In one of the manuscripts of Cristoforo Buondelmonti's Liber Insularum Archipelagi (1420), St. Anthony is depicted in the abstract way used for the other monuments as well-except for St. Stephen, which is the only church depicted with a dome (Fig. 70). However, in the numerous illuminations of the city of Rhodes during the siege of 1480 from Guillaume Caoursin's manuscript in Paris, namely in the ones depicting a bird's-eye view of the town and the port of Mandraki in different stages of the siege, the church is shown as a domed construction with a tripartite division, as seen from the east (Figs. $65 \mathrm{a}, 65 \mathrm{~b}$ ). If this were the main church building, it would in reality have been a rotunda. On the other hand, in the woodcut from the first German edition (1486) of Bernhard von Breydenbach's work, in which the panoramic view of Rhodes depicts the town after the siege and the destructive earthquake that followed in 1481 (the tower of St. Nicholas, the fortifications, and the palace of the Grand Master show visible signs of damage), the site of St. Anthony's church and its cemetery is depicted in a fragmentary manner (Fig. 71). It is as if only parts of the complex have been portrayed: some tomb slabs and a gable-roofed building on the east side are visible, possibly the church. In the west and north parts of the cemetery, there is a series of, respectively, three and seven constructions with gabled arches, perhaps the remnants of the 51 tombs seen by Nicola de Martoni. The same type of building, only enlarged with two annexes, appears in the illuminated manuscript of Conrad Grünenberg (Fig. 72).

It should be noted that the extent to which one can rely, even at a basic level, on this type of depiction is rather problematic, as can clearly be demonstrated in the case of Henricus Martellus Germanus' Insularium illustratum. In the first map, in which the entire island of Rhodes is illustrated, St. Anthony is essentially shown as a single-nave domed basilica (Fig. 73a), while in the second, close-up depiction of the town it is shown as a rotunda (Fig. $73 \mathrm{~b}$ ). In conclusion, no positive affirmation can be expressed concerning the plan, appearance, or other material aspects of the church. 


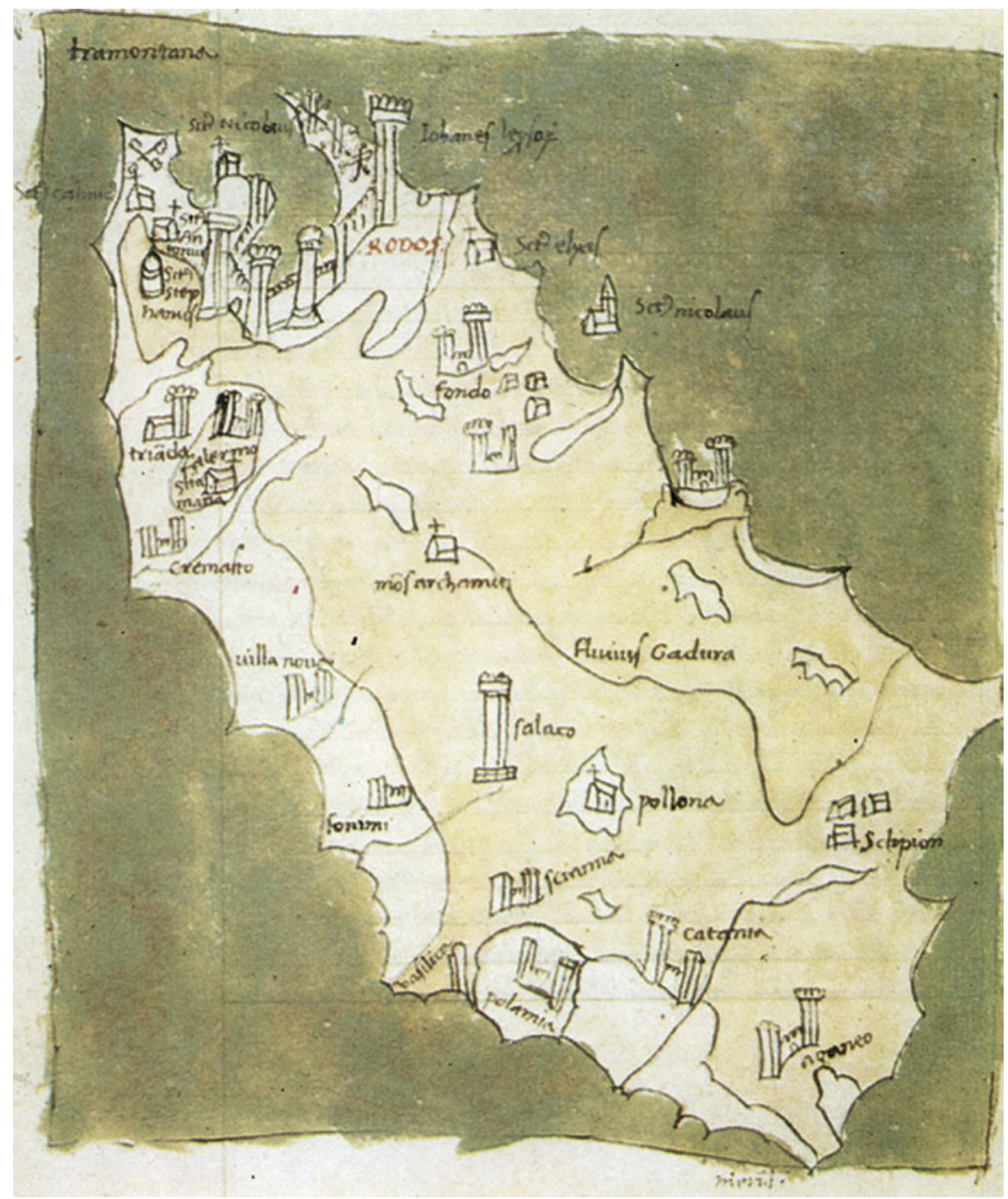

FIGURE 70 Map of Rhodes, 15th century, manuscript illumination

\subsection{Cultic Phenomena}

The church had a miraculous image or figure of St. Anthony, quedam figura sancti Antonii, but it cannot be certain whether this was an icon or a statue. ${ }^{95}$ It bore miraculous properties, attested to by Nicola de Martoni (1394), who narrates that a man, driven by a diabolical spirit, had attacked the image of the saint with a lance, leaving a mark on its face that was still visible in his

95 Bacci 1998, 201. 


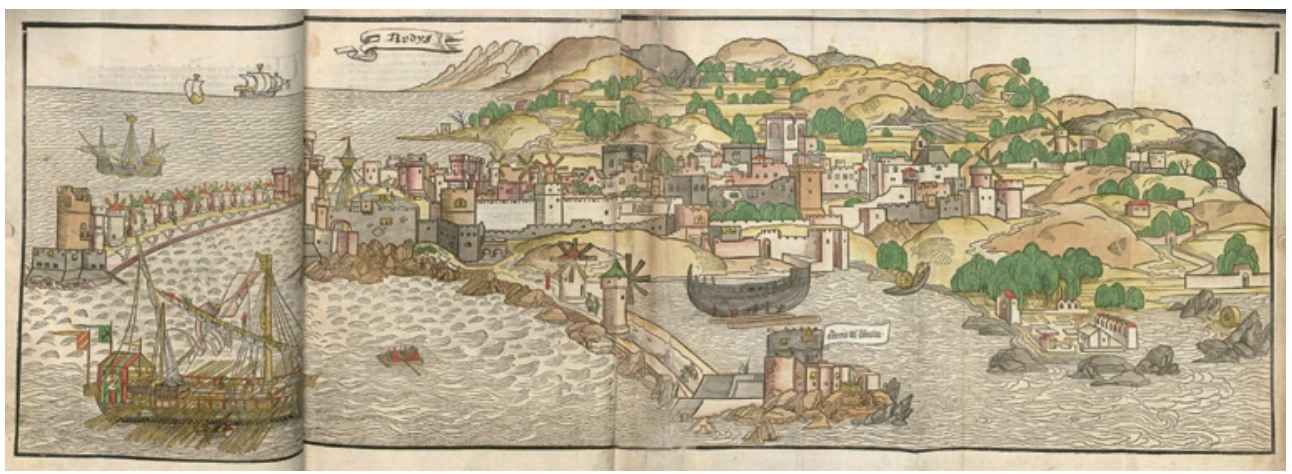

FIGURE 71 Erhard Reuwich, Rhodes, 1486, woodcut

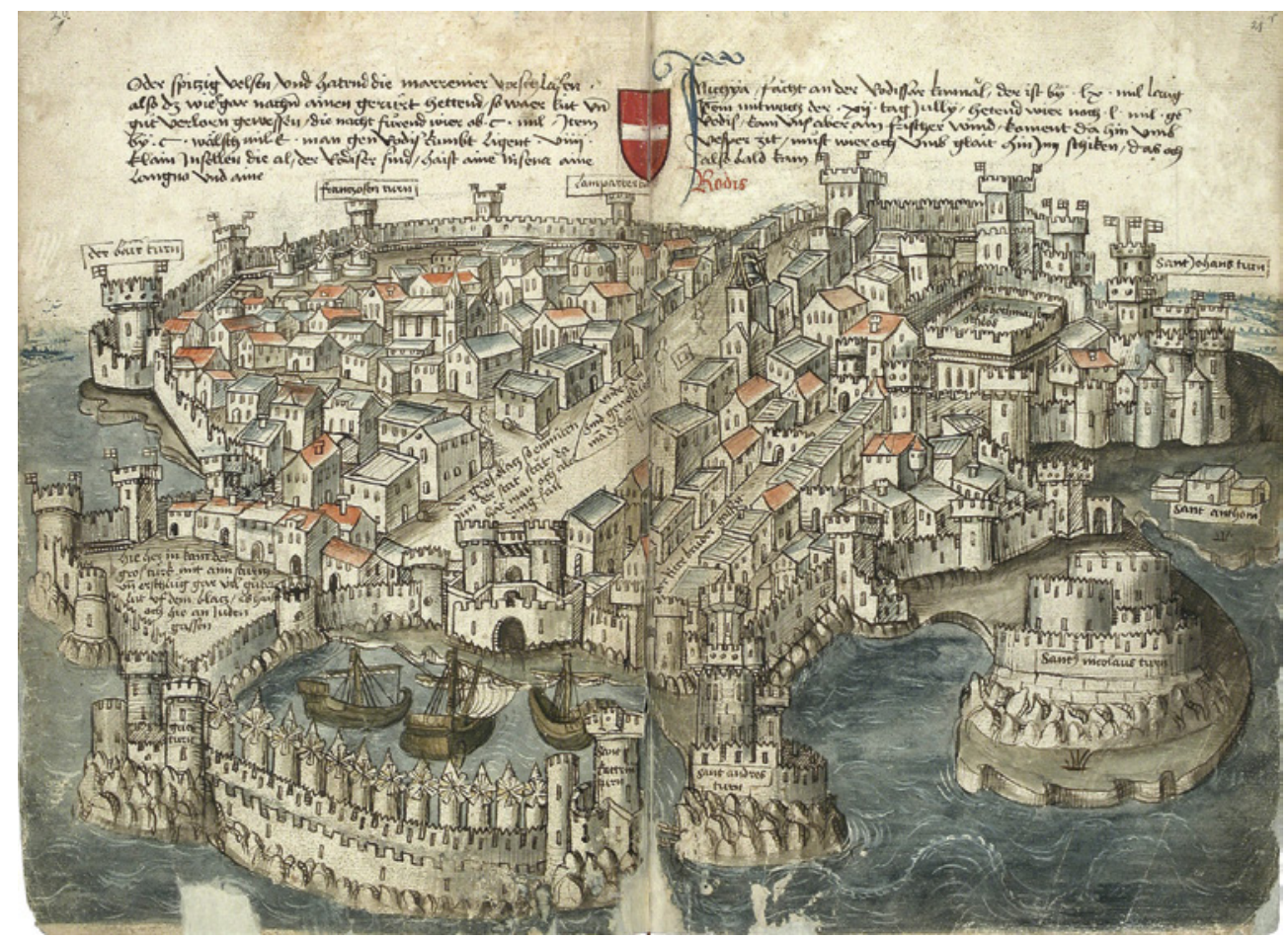

FIGURE 72 Map of Rhodes, ca. 1487, manuscript illumination. Karlsruhe, Cod. St. Peter pap. 32 


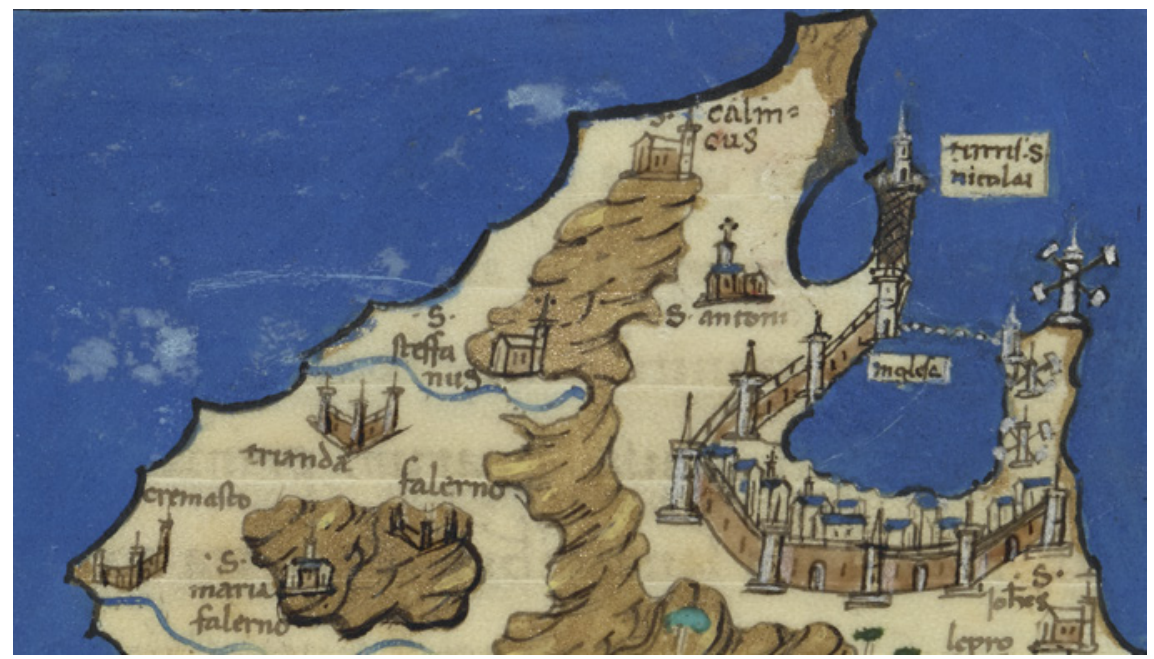

FIGURE 73A Map of Rhodes, ca. 1470, manuscript illumination. London, Add MS 1576o, f. $12 \mathrm{~V}$

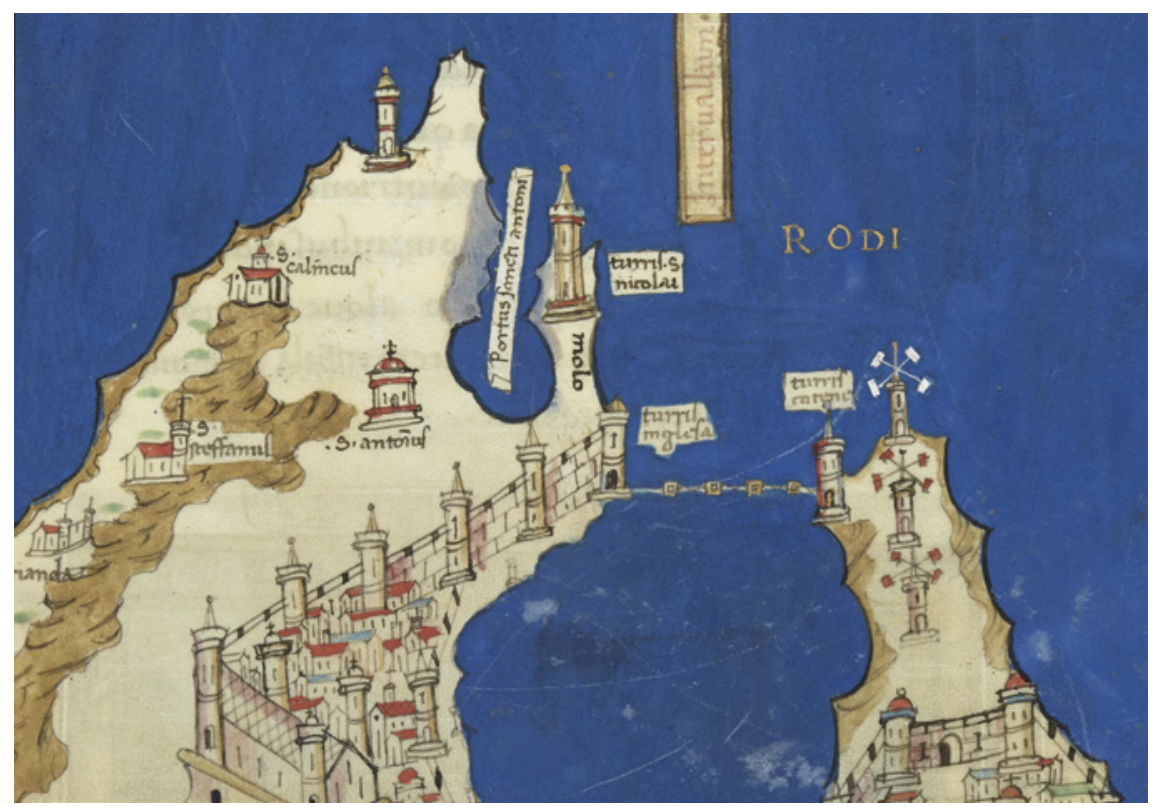

FIGURE 73B Map of Rhodes, ca. 1470, manuscript illumination. London, Add MS 1576o, f. $13 \mathrm{r}$ 
day. Immediately after this blasphemous act, the attacker was struck with "St. Anthony's fire," and, his body burning like a piece of wood, he rushed into the sea only to suffer even more. ${ }^{96}$ In remembrance of the miracle, the image of the saint, apart from the mark on its face, had the iron part of the lance hanging in front of it. The description reveals that its miraculous powers were well-known, evidenced by the presence of many silver and ship-shaped $e x$ votos and candles. ${ }^{97}$

It is of interest that a miraculous image of St. Anthony was transported to Malta with the Knights, as is testified by a 17th-century document mentioning "la santa e miracolosa imagine di Santo Antonio, che fu portata da Rodi." More specifically, it was decided in 1603 to transfer the miraculous image of St. Anthony, which had arrived in Malta from Rhodes, from the borgo to the collachium, to the church in the vicinity of the auberge of Provence. ${ }^{98}$ Perhaps this was the Baroque church of Our Lady of Victory, the first building erected in the newly founded city of Valletta in 1566 (the city's foundation stone is purported to be located within it), commemorating victory during the Ottoman "Great Siege" of 1565. In 1617 it was made a parish of the Order and was dedicated to St. Anthony the Abbot; thus the presence of the miraculous image

96 St. Anthony had been associated with the disease ergotism-erysipelas, regarded as the same in the Middle Ages; his patronage, and especially contact with his relics, would provide a cure. The disease was known as ignis sacer, or St. Anthony's fire, and its symptoms were also interpreted as demonic possession. When the relics of the saint were taken to La-Motte-Saint-Didier in France, their powers over the disease were so great that a hospital was set up for the benefit of the people afflicted with the illness by the Hospital Brothers of St. Anthony, or Order of St. Anthony, founded in 1095 by a nobleman of the Dauphiné whose son had been miraculously cured. Pope Urban II designated Anthony as the saint against the disease. See Butler 1886, 175-176, esp. note $\dagger$; Sebastian 1999, "Ergotism," "St Anthony's Fire;" Farmer 2011. On the late medieval worship and iconography of the saint, see Fenelli 2011.

97 "De sancto Antonio et ejus miraculo Est in dicta ecclesia Sancti Antonii quedam figura sancti Antonii de qua magnum recitatur miraculum: quod quidam spiritu diabolico instigatus dedit cum quadam lancea et percussit dictam figuram in faciem, cujus ictus vulnus adhuc apparet in facie dicte figure. Et statim, dato dicto ictu, accensus fuit ingne beati Antonii, ita quod ardebat corpus suum sicut si fuisset lignum, et ille infelix peccator videns se sic accensum projecit se in mare, quod erat prope, ut ignis extingueretur, quo projecto tanto plus ardebat corpus suum in mare, et statim totum suum corpus fuit mirabiliter combustum. Ferrum dicte lancee stat suspensum ancte (ante) dictam beatam figuram, et multe ymagines argentee et multa alia vota navium et cerei sunt in dicta ecclesia;" Piccirillo 2003, 28.

98 Mdina, Асм Misc. 611, f. 59r. The manuscript is dated 169o, under the Master Adrien de Wignacourt (169o-1697) and provides a copy of the original deliberation of the chapter general of the year 1609 . 
there would be fitting. ${ }^{99}$ Currently, in the apse that was enlarged in 1699 there are two icons flanking the titular painting of the Birth of the Blessed Virgin behind the main altar: one with St. Anthony the Abbot and the other with St. Anthony of Padua (Figs. 74a, 74b). ${ }^{100}$ These two works are said to have come from Rhodes and were taken to the church on July 16 th, 1617 , previously having been kept at St. Anthony in the borgo. ${ }^{101}$ It would be rather unfounded to suppose that this icon of St. Anthony the Abbot could be the one mentioned in the document of 1603 , since its treatment does not fit with the established practices associated with miraculous icons, especially as far as its location in the church and, thus, its accessibility are concerned.

The Master Villeneuve's initial decision to be buried in St. Anthony's cemetery seems to have been linked with another miracle, one concerning a drowning chaplain. ${ }^{102}$ In 1346 , invoking the many miracles in the church, Pope Clement vi granted indulgences for visitors "in the cemetery in which deceased fratres and pauperes of the hospital are buried." ${ }^{103}$ As a result, the pilgrims visiting Rhodes made use of this opportunity: in 1418 Nompar de Caumont reported that absolution à peyne et coupe [from punishment and guilt] was granted to pious visitors every week on Monday, Wednesday, and Friday, which is why, he admits, he went many times to hear the mass. ${ }^{104}$ Later on, this would also serve as an opportunity for some pilgrims to visit the tombs of friends or relatives, fellow pilgrims of the past years.

The miracles at the church seem to have been connected not only to the aforementioned image, but also to the site itself. The indulgences granted had surely added to the sanctity of the church's space and must have been gradually further transposed to the buried themselves. When the pilgrim Georges Lengherand visited the town in 1485 , he was informed of many miracles and referred to a wondrous event concerning a Knight who had been killed during the Ottoman siege of 1480. Because of the presence of the Ottomans around St. Anthony, the Knight was entombed in one of the Greek churches of the town; but a year after his passing, when he was exhumed so as to be transported to

99 Ferris 1866, 185-190; Thake 1995; webpage of the National Trust of Malta: www.ourlady ofvictory.org.mt/pageoı.html; National Inventory of the Cultural Property of the Maltese Islands: culture.gov.mt/en/culturalheritage/NICPMI_Database/ooo35.pdf, both accessed October 21st, 2019 .

100 Close examination of the icons was not possible, as access to the altar was limited when the author visited Valletta in autumn 2016.

101 Ferris $1866,186-187$.

102 Luttrell 2003b, 183.

103 Idem, 182.

104 La Grange 1858, 83. 


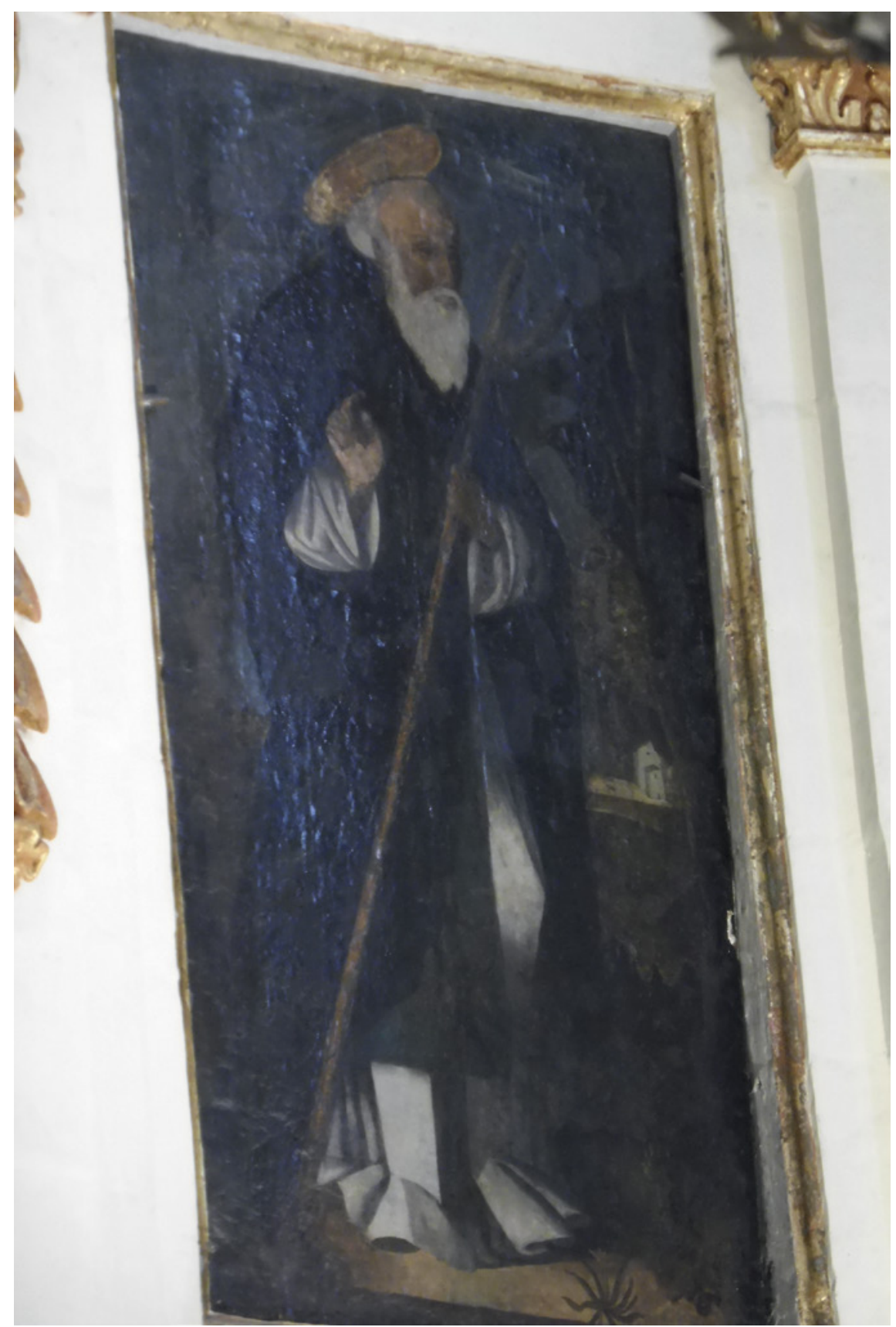

FIGURE 74A St. Anthony the Abbot, church of Our Lady of Victory, Valletta 


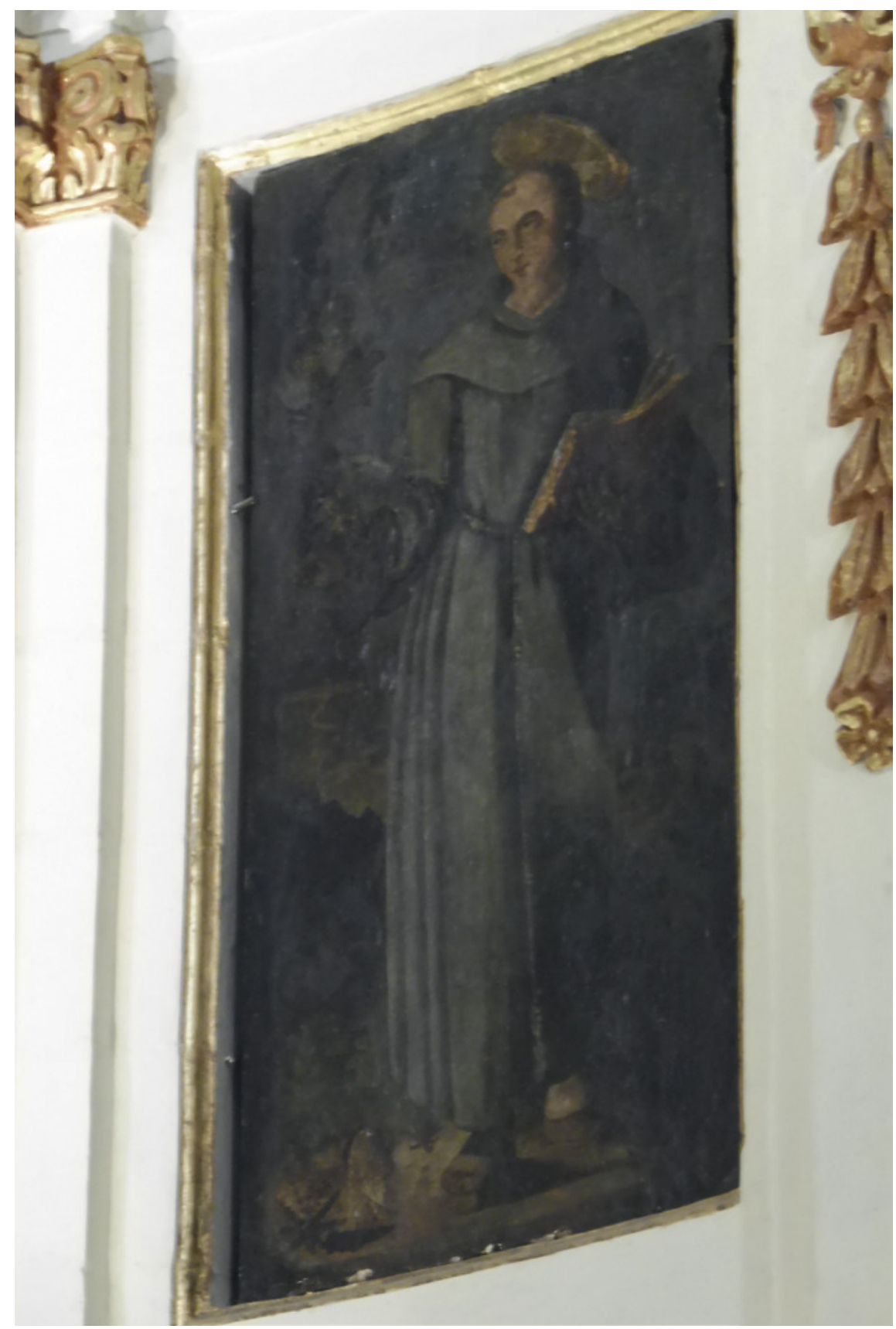

FIGURE 74B St. Anthony of Padua, church of Our Lady of Victory, Valletta 
St. Anthony, his corpse was found unchanged, with no signs of decomposition and with the marks of his wounds the same as the day he had died. ${ }^{105}$ The incorruptibility of bodies as a strong indicator of sanctity was a widespread notion in the Middle Ages. ${ }^{106}$ However, this legendary tale could hint at a possible popular belief in Rhodes concerning the cemetery's role in the brethren's afterlife: it would have served as their sole, proper, and ultimate resting place; and as the dead Knight's body could not undergo the stage of physical decomposition, his soul would have remained in suspense as well, unless he was transferred to St. Anthony. ${ }^{107}$

The non-decomposition of the body cannot but bring to mind-by contrast - the quality of the Jerusalem Akeldama, which consumed corpses in just a few days; ${ }^{108}$ even more so because Akeldama was the burial ground of pilgrims from the late 6th century and had been granted to the Hospitallers in 1143 by the Patriarch of Jerusalem, William of Malines. ${ }^{109}$ Until 1187, when Saladin took Jerusalem, the Order was responsible for the burial of the sick and the pilgrims at the site's charnel pit, which continued to serve as the burial site for the Christians of Jerusalem after the fall of the city. The site was included as a station in the pilgrim itineraries, and in the 14th century indulgences were granted to its visitors, who recited prayers for the people buried there. ${ }^{110}$ It could be that the burial site's miraculous power was still echoing in the Rhodian setting of the Order's cemetery, St. Anthony, and resulting in the abovementioned - and probably other-stories. Besides, by the $15^{\text {th }}$ century, the concept of earth being transferred from Akeldama to other burial sites, which were subsequently imbued with its properties, seems to have been wellestablished. ${ }^{111}$ There are no clues of such a practice at Rhodes, but it cannot be excluded that the role of the Hospitallers as former custodians of Akeldama could by then have been deemed sufficient for such a connection.

\footnotetext{
105 Godefroy-Ménilglaise 1861, 106.

106 Angenendt 1991, 320-348.

107 It is worth mentioning that this notion, concerning the tie between the body not being properly decomposed and the soul being imprisoned in an intermediate state, would later be found in the popular beliefs concerning revenants or vampires. See, for example, the cases of the Balkans and Greece during the modern period; Danforth 1982, 36-37; Barber 1988; Čajkanović 1998, 72-84; du Boulay 1998, 85-108.

108 Bodner 2015, 74-93; Bacci 2017a, 135 .

109 Riley-Smith 2012, 76-77.

110 Donkin 2017, 112.

111 For example in the Campo Santo Teutonico in Rome, in the Camposanto in Pisa, and in Nicosia; idem, 109-126.
} 
In conclusion, it seems that the church of St. Anthony was invested with particular cultic meaning during the Hospitaller period at least from the late 14th century, a result directly related with the image it held, the indulgences granted, its use as the brethren's and pilgrims' cemetery, and the interconnection of these factors with the miracles performed. From this point of view, it cannot be excluded that the aforementioned Gothic silver-gilt reliquary with relics of the saint and the arms of the Master Jean de Lastic (1437-1454), which was taken from Rhodes to Malta and was still present there in the 18th century, could at some time have been kept in this church.

\section{St. John the Baptist de Fonte}

The church of St. John the Baptist de Fonte (Sanctus Johannes Baptiste de Fonte,

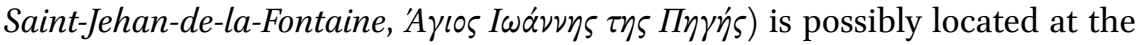
site of an underground crypt in Venetokleon St., in the southeastern part of the town outside the walls, around 450 meters south of the Acandia Gate and 800 meters southeast of the Gate of St. John, which perhaps took its name from this church. ${ }^{112}$ Its location is stated in Hospitaller documents of 1427 as outside the walls, extra menia civitatis nostre Rhodi situata. ${ }^{113}$ The area comprised the quarter of St. George, and the specific neighborhood was called in modern

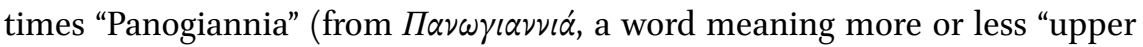
St. John").114

According to an anonymous German pilgrim traveling in 1444, the church was located in the middle of a garden, the most beautiful he had ever seen. ${ }^{115}$ Wilhelm Tzewers (1477-1478) and Jacob Kreynck (1479) are more specific, stating that it lies near the garden of the Grand Master, known as "paradise."116

\footnotetext{
112 Manoussou-Ntella 2014, 301-332; Manoussou-Ntella 2013, 62.

113 Tsirpanlis 1995, 106, 240; Hattersley-Smith 200o, 495.

114 Papachristodoulou 1972, 300. Papachristodoulou does not identify St. John de Fonte with the underground chapel; instead he thinks that the former had been a large church that was not extant and that the latter had been called Panogiannia (upper St. John) as compared to the bigger church. It seems, though, that the crypt could have been part of the larger edifice.

115 "Item Rodis hat die aller schonsten garten, die ich al mein tag nie gesechen hab, von allerlai frucht, der man sich getengen mag; daz sprich zo warhait. vnd leid ain kirch bei miten in den gerten, die hoset sant Johans kirch, des tefers, vnd ist ain prun jn der kirchen, da ist sant Johanes haubt jn funden worden;" Birlinger 1867, 302-303.

116 "Est prope ortus magnus dominorum, qui dicitur paradisus;" Hartmann 2004, 110. "Niet ver vandaar ligt een boomgaard, die eigendom is van de Heren van Rodys, en die heet 'het
} 


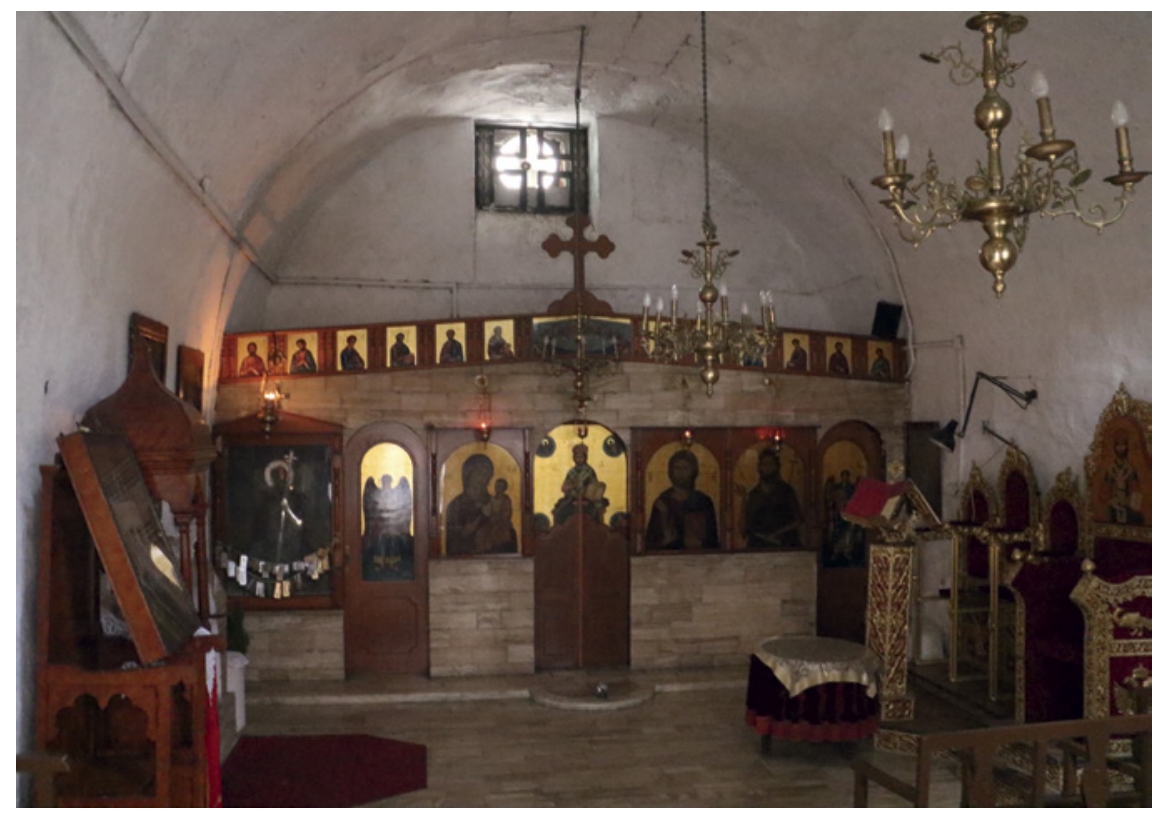

FIGURE 75A St. John the Baptist de Fonte, Rhodes. View to the east

This must not have been the garden that lay on the north side, on top of the palace's bastion, ${ }^{117}$ to the northwest of the city, since the underground chapel perhaps identified with the church is at the southeast; but the reference could point to other properties of the Master. The scarcity of material and textual evidence does not allow further hypotheses, and the indication FONDO in one of Cristoforo Buondelmonti's maps (Fig. 70) points to the castle of Afandou. ${ }^{118}$

The present-day crypt in Venetokleon St. is covered with a barrel vault, and the spring with holy water is at its north wall (Figs. $75^{\mathrm{a}}, 75^{\mathrm{b}}, 75^{\mathrm{c}}, 75^{\mathrm{d}}$ ). At the beginning of the 2oth century it was recorded that there were remains of wall paintings depicting St. John the Baptist holding a banner with the inscription, in Gothic script, Ecce agnus dei ecce qui tollis pecata mundi; ${ }^{119}$ the walls are currently covered with white paint. The crypt had perhaps been part of a large Early Christian basilica ${ }^{120}$ and has been thought to have been linked to a tradition already existing before the Knights arrived on Rhodes. ${ }^{121}$

Paradijs';" Gaspar 2013, 8-9.

117 Manoussou-Ntella and Ntellas 2004, 239, 247, 25 o.

118 Heslop 2017, 177-198.

119 De Belabre 1908, 80; Gabriel 1923, 211.

120 Manoussou-Ntella 2014, 62.

121 Sommi Picenardi 1900, 161-162. 


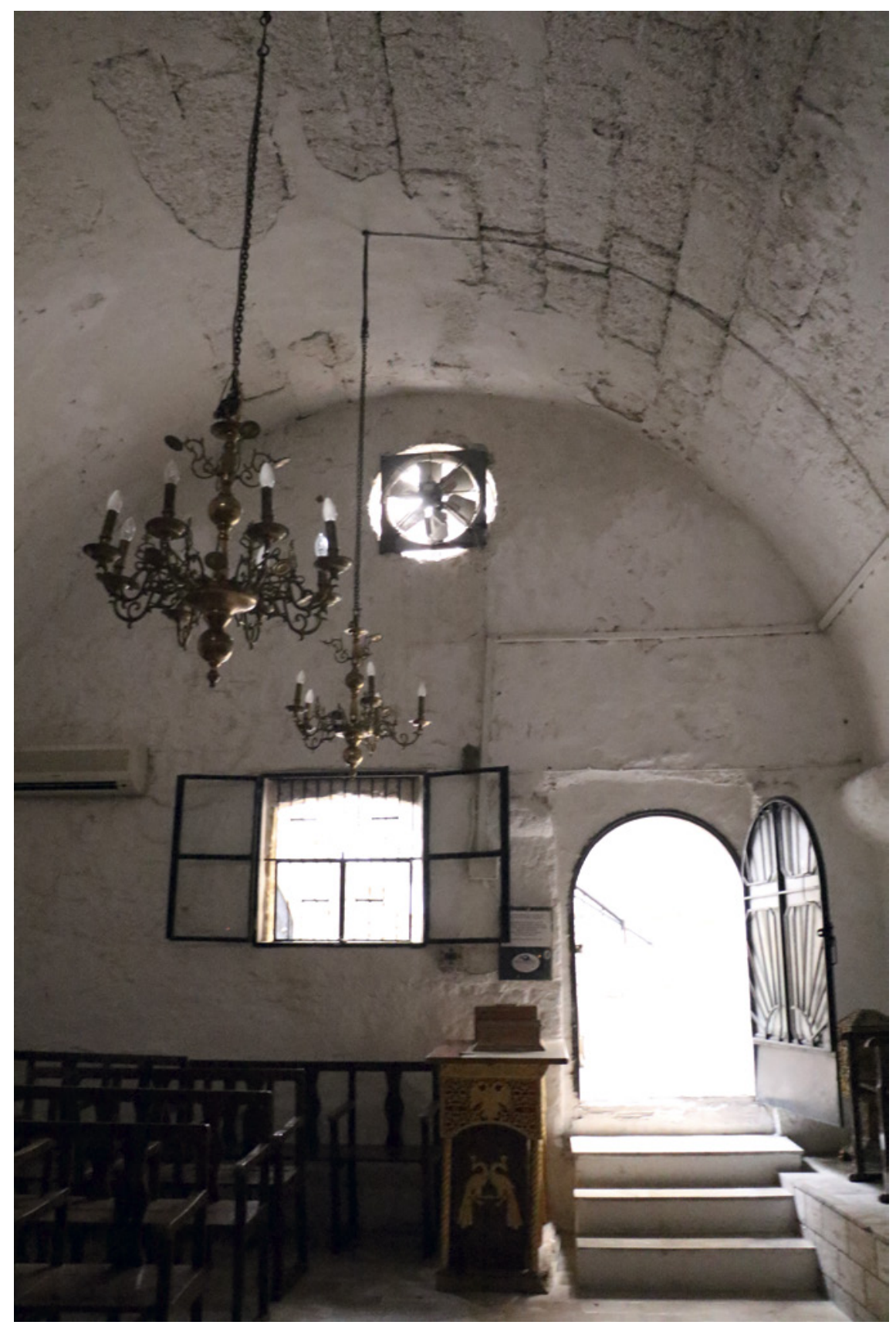

FIGURE 75B St. John the Baptist de Fonte, Rhodes. View to the west 


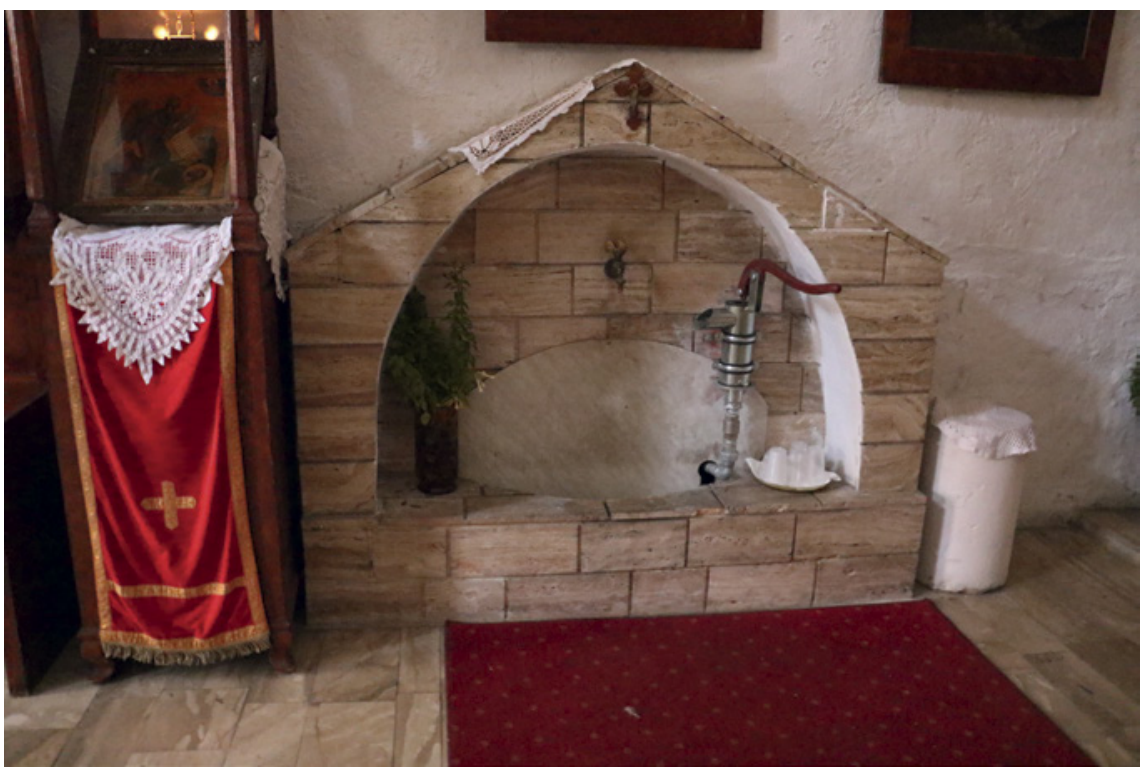

FIGURE 75C St. John the Baptist de Fonte, Rhodes. Spring with holy water

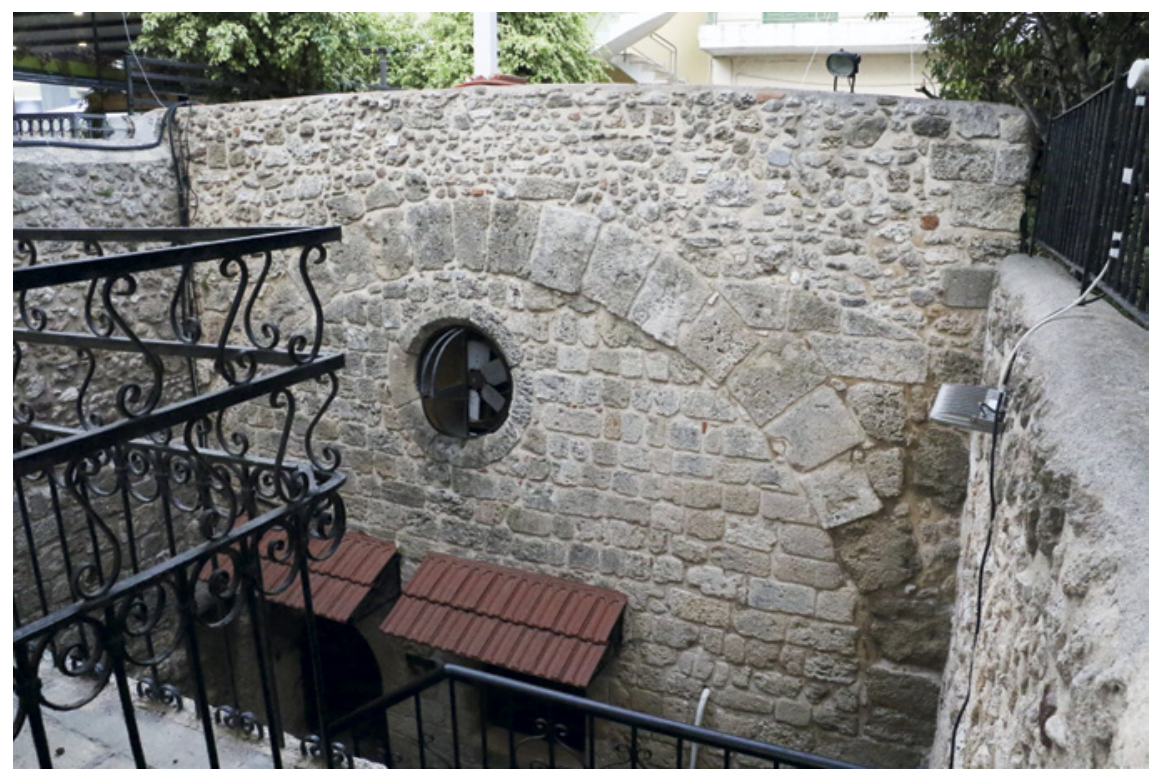

FIGURE 75D St. John the Baptist de Fonte, Rhodes. Western entrance 
It is not listed in the group of 19 churches outside the walls that were demolished in 1481 so as not to be used by the enemy in a possible upcoming attack, as had happened in the siege of $1480 .{ }^{122}$ Perhaps this indicates that the edifice had already been destroyed during the siege and that the small crypt that remained was not considered worthy of further attention, since the chapel was still in use in 1495, according to Wolfgang Zillenhart. ${ }^{123}$

A late 15th-century register found in the Archives of the Order in Malta, which lists the establishment of chapels and perpetual masses by various masters and other people at Rhodes, indicates that St. John de Fonte was founded and endowed by Dragonetto Clavelli: "Cappella Sancti Joannis de fonte fundata per dominum dragonono clavelli prout retulit frater."124 The source of this information is an unknown brother of the Order with a note that the foundation document was not found-“fundatio non est inventa"-which may lead to doubts concerning the credibility of the report. ${ }^{125}$ There is no clear evidence as to whether Clavelli was a Latin or a Greek; both have been supported, but, bearing in mind his position as procurator of the Master and vassal of the Order, it seems clear that the former or even a mixed identity seems more likely. It is evident that he was not Orthodox - he was married to Agnese Crispo, daughter of Francesco I, Duke of the Archipelago, and was buried at the Augustinian church in the town, where he commissioned his funerary chapel dedicated to St. Nicholas; he died in $1415 .{ }^{126}$

The issue of Clavelli's identity proves to be of importance, since it would enable an understanding of the cultic character of the monument. If the frescoes in St. John de Fonte had been executed under his patronage, this would explain the inscriptions in Latin. From the pilgrim's point of view, the church belonged to the Greek rite, but Latins could also celebrate mass there, as reported in $1418^{127}$ and $1479 ;^{128}$ this would most probably mean that in their eyes the church seemed Greek. This corroborates the hypothesis that, if Clavelli did found the

\footnotetext{
122 Bosio 163o, 431-432.

123 "Item an dem anderen ortt der statt ligt ain cappell haist zu sant Johans, da ist ain prun, jn sol für das fieber sein;" Gebele, "Die Pilgerreise," 114.

124 Valletta, AOM 53, 32v (11v).

125 Luttrell and O'Malley 2019, 6o, note 68.

126 Luttrell 1989, 11, with bibliography; Luttrell 1992b, 218, note 143. Tsirpanlis seems certain that Clavelli was Greek; Tsirpanlis 1991, 331-335; Tsirpanlis 1995, 81-83, 248-249. Concerning his funerary chapel, see Ntellas 2000a, $5^{0}-53$.

127 "[...] en lequelle chapelle ha de grans pardons, he je y estoie le reste de saint Jehan décollacé et là fis chanter messe et si ay-je esté depuis; et celle chapelle tiennent les Grexs;" La Grange 1858, 82.

128 “[...] een Grieks-orthodoxe kerk;” Gaspar 2013, 8-9.
} 
chapel at some point before his death, it must have been part of or replaced an Orthodox edifice. As a Latin he could have endowed a chaplaincy in a Greek church to attract pilgrims and revenues.

The affairs of the church were regulated by the Hospitallers, as was the case with the Orthodox institutions on the island. In 1427 it was granted to the Greek priest ( the obligation on his part to care for and repair the church and its houses, to cultivate its gardens, and to pay 12 Rhodian florins per annum to the Prior of the Conventual church. ${ }^{129}$ The priest was said to have belonged to the family that was traditionally in charge of this church. It was decided that the Prior would appoint a chaplain of the Order to offer mass three times per week, that the candles would be bought at Chiona's expense, and that he would own the contributions of the faithful unless they were silver or jewels, in which case they were to be handed over to the Prior. Nevertheless, in 1430 this decision was annulled, because Chiona left the church; the housed was deserted, the gardens were uncultivated, and, moreover, it was discovered that he had lied when he made his request to the Order. Surely the cultic status of the church was intertwined with the economic aspects resulting from its devotional use. Its popularity must have generated a considerable income from donations, thus attracting the Hospitallers' interest in securing the most valuable ones. At the same time, perhaps Chiona's aspirations were in part opportunistic as well, which would explain why he went so far as to deliver false statements in his effort to obtain the control of the church.

St. John remained under the Order's command. In the years of the Master Giovanni Battista degli Orsini (1467-1476), it was decided to compile an inventory of the properties of the chapels of St. John of the Collachium, of St. Anthony, of Our Lady of Phileremos, of St. John de Fonte, and of other churches in the jurisdiction of the Convent. ${ }^{130}$ The statute determined that two commissioners would have the task of visiting the sites and all their possessions, of composing inventories, and of investigating whether divine worship was regulated according to the proper and righteous institutions. The specific mention of only these four churches could be interpreted as indicative of their cultic importance, which would be reflected in the properties and the religious practices associated with them; this may be why they appear to be considered as a distinct group in the Hospitallers' record. The Master's care is documented

\footnotetext{
129 Tsirpanlis 1995, 106, 239-241.

130 "[...] pertinentia capellis ecclesie sancti Ioannis collaci Rhodi et ecclesiis sancti Antonii, nostre domine de Philermo, sancti Ioannis de fonte et omnium aliarum in Rhodo constitutarum iurisdictioni religionis nostre;" Stabilimenta, De ecclesia 36.
} 
by two of the objects belonging to the chapel's treasures: a missal bearing the arms of Orsini and a silver chalice with a crucifix on the foot and a paten, donated by an unnamed Grand Master. ${ }^{131}$

St. John de Fonte was invested with exceptional meaning as, according to legend, when some men dug up a well at the site, they discovered the head of St. John the Baptist, and a spring of water miraculously appeared. ${ }^{132}$ This legend may have been established before the arrival of the Knights on the island; in the 12th century it was thought that Herod had actually built the city of Rhodes and that he went there-apart from Nineveh-after the Baptist's decapitation. ${ }^{133}$ The discovery of the head of the Baptist at Rhodes was merely a local legend; traditionally, three inventions of the head have been recorded. The first finding had taken place in Jerusalem, where two monks found the head in a pot, after John appeared to them in a vision and instructed them accordingly. The monks met a potter, who left with the head and took it to Emesa. The second encounter was by the monk Markellos at Emesa in the mid-5th century; a church was subsequently built by the bishop of the city, Uranius, to house the relic. Finally, the third discovery took place at Comana in Cappadocia in the mid-gth century, when the head was taken to Constantinople, where it was placed at the Monastery of Stoudios, dedicated to the Baptist. ${ }^{134}$

The existence of the church before 1309 would be, then, connected with the ancient tradition. The sanctuary is not mentioned during the 14th century, but by its end or the beginning of the 15th century it must have become popular among the Latins, as demonstrated by Clavelli's patronage and the pilgrims' reports. Specifically, by 1418 indulgences were granted to its visitors: Nompar de Caumont reports that one could obtain considerable pardons there and that he celebrated mass on the Feast of the Beheading of the Baptist. ${ }^{135}$ Moreover, the water of the spring was holy and thus miraculous: according to Wolfgang Zillenhart (1495-1496) it had the power to cure fever. ${ }^{136}$

131 "Primo calix unus argenti cum patena et crucifix in pede quem dedit prefate capelle reverendissimus dominus cardinalis et magnus magister Rhodi dignissimus [...] Missale unum in pergameno cum armis quondam reverendissimi domini magistri Ursinis;" Valletta, АОМ $53,32 \mathrm{~V}(11 \mathrm{v})$.

132 La Grange 1858, 82; Geisheim 1858, 213; Kamann 188o, 126-127; Birlinger 1867, 302-303; Hartmann 2004, 110; Gaspar 2013, 8-9; Gebele 1932-1933, 114; Sommi Picenardi 19oo, 161.

133 Sommi Picenardi 190o, 161, where he sites Benedict of Peterborough; see Stubbs 1867, 198; Torr 1887,70 .

134 For a detailed discussion of the sources, see Du Cange 1665; Maraval 1985, 23-6o.

135 La Grange 1858, 82.

136 Gebele 1932-1933, 114 . 
The church's joint use by Greeks and Latins seems to have emerged from its cultic importance, as evidenced by the testimonies of pilgrims in the 15th century. Shared devotional practices in the Eastern Mediterranean have been recorded, especially concerning places of pilgrimage in rural areas, as well as in urban centers, notably in Cyprus, Euboea, Achaia, and Crete. ${ }^{137}$ Even though there is little documentation for St. John de Fonte, it appears that it belonged to an older Orthodox complex and was taken under the care of the Order in the late 14th century or the early 15 th. The sources reveal that the Hospitallers did not interfere with the material setting of the church; it was thus recognized as a Greek sanctuary, although there probably was a Latin patron around the beginning of the $15^{\text {th }}$ century. How exactly this convergence was facilitated at this small Rhodian monument cannot be clarified due to the lack of evidence. The dedication to John the Baptist, the patron of the Order, a pre-existing legendary background, and the site's promotion by one of the most powerful men on the island seem to have elevated its potential as another spot in the town's cultic network; the Knights subsequently promoted it successfully to the Western pilgrims who passed by, also taking advantage of its revenues.

\subsection{Historical and Archaeological Investigation}

The Latin church of Our Lady of Victory and the Greek church of St. Pantaleon shared a common history and as such they are treated together. Their story commenced during the important final battle of the Ottoman siege of 1480 , when on the morning of July $27^{\text {th }}$ - the feast day of St. Pantaleon-the Ottomans assaulted the town from the already bombarded and mostly collapsed walls of the Italian sector, at the east end of the borgo, known as the Jewish quarter. The besieged were caught by surprise, and their response was delayed; but the Master Aubusson and his troops hastened to the walls, where the Ottomans ultimately found themselves confined between the already destroyed fortifications and some new ones that Aubusson had insightfully started building behind the former. The Hospitallers, the natives, and the merchants who participated in the battle fought strongly, and Aubusson was heroically wounded five times. When the banner of the Order with Christ, the Virgin Mary, and St. John the Baptist was raised in battle, the Ottomans saw a golden cross in

137 See recently Mersch 2015, 461-484, with bibliography. 
the air, along with a shining maiden holding a shield and a spear and a man in peasant garb; they were terrified and fled the battle scene. ${ }^{138}$

To commemorate the event and in gratefulness toward the Virgin, Aubusson commissioned the construction of Our Lady of Victory and St. Pantaleon at the location of the breach. ${ }^{139}$ The miraculous apparition of the Virgin in arms became famous through the account of Guillaume Caoursin, written just after the siege. In 1484 a delegation, in which he himself participated, was sent by the Grand Master to the pope to report the incidents of the siege and the prodigious event. The following year, Innocent VIII issued the Redemptor Noster bull, approving the erection of the churches of Our Lady of Victory and St. Pantaleon in memory of the event, as well as of other churches and chapels. ${ }^{140}$

For the construction of the churches, Aubusson bought at his own expense many of the Jewish houses in the area that had been destroyed during the attacks, and many other Knights who had taken part in the fight made their own contributions. ${ }^{141}$ The Grand Master also endowed the churches with properties, ornaments, sacred vessels, and supplies. ${ }^{142}$ Moreover, he had an inscription sculpted on top of the entrance door of Our Lady of Victory that related the events and his battle wounds. ${ }^{143}$ This was probably the inscription documented in the Franciscan archives of Neochori in 1743, which read Ob insignem victoriam de Turcis a coelo Rhodiis demissam ecclesiam Sanctae Mariae de Victoria Petrus Daubusson Magister erexit McccCLXXX ab Inc. XII Augusti. ${ }^{144}$ On one of the altars of the church, there was a panel depicting the battle and the miraculous events, probably like the one at Épernay (Fig. 66). ${ }^{145}$

The duration of the works is not certain. According to Jehan de Tournai, the construction of the church of the Virgin had just started in 1488, but it was not yet finished in 1491, when Dietrich von Schachten visited the town. ${ }^{146}$ When

138 Concerning the siege, see recently and with further bibliography de Vaivre and Vissière 2014; Vann and Kagay 2015 .

139 Bosio 1630, 506; Sommi Picenardi 1900, 111. This was also mentioned by many pilgrims, as the miracle and Aubusson's commission had become commonly known.

140 Ferraris di Celle 1988, 31-32.

141 Sommi Picenardi 1900, 111-112; Gabriel 1923, 180. According to Jewish sources, it was thanks to the God of Israel that the Ottomans were defeated and d'Audusson built the churches on either side of the synagogue that stood there or in its place; see Kollias 2007, 290-291.

142 Kollias 2007, 290-291.

143 Reported by the English Anonymous (148o-1526) and Jan Hasištejnsky z Lobkovic (1493); Brefeld 1985, 152; Strejček 1902, 45 .

144 Sommi Picenardi 1900, 112; Gabriel 1923, 181.

145 Reichert 2005, 164-165.

146 Blanchet-Broekaert and Péricard-Méa 2012, 181-182; Röhricht and Meisner 188ob, 184. 
the Ottomans attacked Rhodes again, it was deemed necessary to demolish a part of the churches in order to reinforce the inner part of the fortifications, as the Italian sector was the weakest, and the Ottomans launched persistent attacks. ${ }^{147}$ In 1743, based on the aforementioned document in the Franciscan archives, the church was more or less standing, with its doors walled.

Aubusson granted the church of Our Lady of Victory to the Franciscans in 1497, along with its chapels and annexes. ${ }^{148}$ Paul Walther Guglingen (1481), a German Franciscan, provides insightful information concerning this action; during his stay at Rhodes, he was hosted by the Franciscans, who were installed inside the town in a very small church, St. Mark, which used to be Greek, ${ }^{149}$ since their convent outside the walls had been destroyed during the siege. They explained to him that if the Grand Master did not grant them an appropriate space, they would leave for Candia. ${ }^{150}$ Thus, the decision of Aubusson ensured their stay in the town.

The Franciscans occupied the church of St. Mark in the borgo sometime before 1457 and until 1490; ${ }^{151}$ as mentioned, until the destructive siege of 1480 they also held a convent outside the walls, dedicated to the Virgin. ${ }^{152}$ They were the second missionary order to be installed at Rhodes, as the Augustinians held a convent dedicated to St. Augustine at least since ca. 1317-1320, possibly the one known as dedicated to St. Bernard or St. Bernardin of the Franciscans to the southwest of the borgo; ${ }^{153}$ it was mentioned in 1339 and must have become an important Latin church in the town. ${ }^{154}$ Burials of Latin pilgrims linked to the mendicants took place at both. ${ }^{155}$ In 1494 a fellow traveler of Pietro Casola, the Franciscan Francesco Trivulzio, died during the journey and was buried in front of the altar of Our Lady of Victory. ${ }^{156}$ In 1519 the famous humanist Peter

\footnotetext{
147 Bosio 163o, 691.

148 Tsirpanlis 2012, 233; pilgrims refer to the Franciscans; see Brefeld 1985, 152; Röhricht and Meisner 188ob, 184; Strejček 1902, 45; Muller 2016, 33; de Salignac 1593, 148.

149 The church occupied $17 \mathrm{~m}^{2}$; see Maglio 2016a, 162; Maglio 2016b, 58-59.

150 Sollweck 1892,87 .

151 Luttrell 1992b, 210; Maglio 2016a, 162.

152 See the testimonies of Alessandro di Filippo Rinuccini (1474) and Jehan de Tournai (1488-1489). According to the former, one of his fellow travelers (a Frenchman who had died on board of the ship) was buried there; Calamai 1993, 75-76; Blanchet-Broekaert and Péricard-Méa 2012, 181-182. See also Maglio 2016a, 156.

153 On the dating, see Tsougkarakis 2012, 250-251. Concerning the identification of the Augustinian convent, see Ntellas 2000a, 43-54; Maglio 2016a, 153.

154 Luttrell 2003b, 145, 179 .

155 Concerning the Augstinians, see Weller 1586, n.p.; von Minckwitz 1856, 101.

156 Paoletti 2001, 244-245.
} 


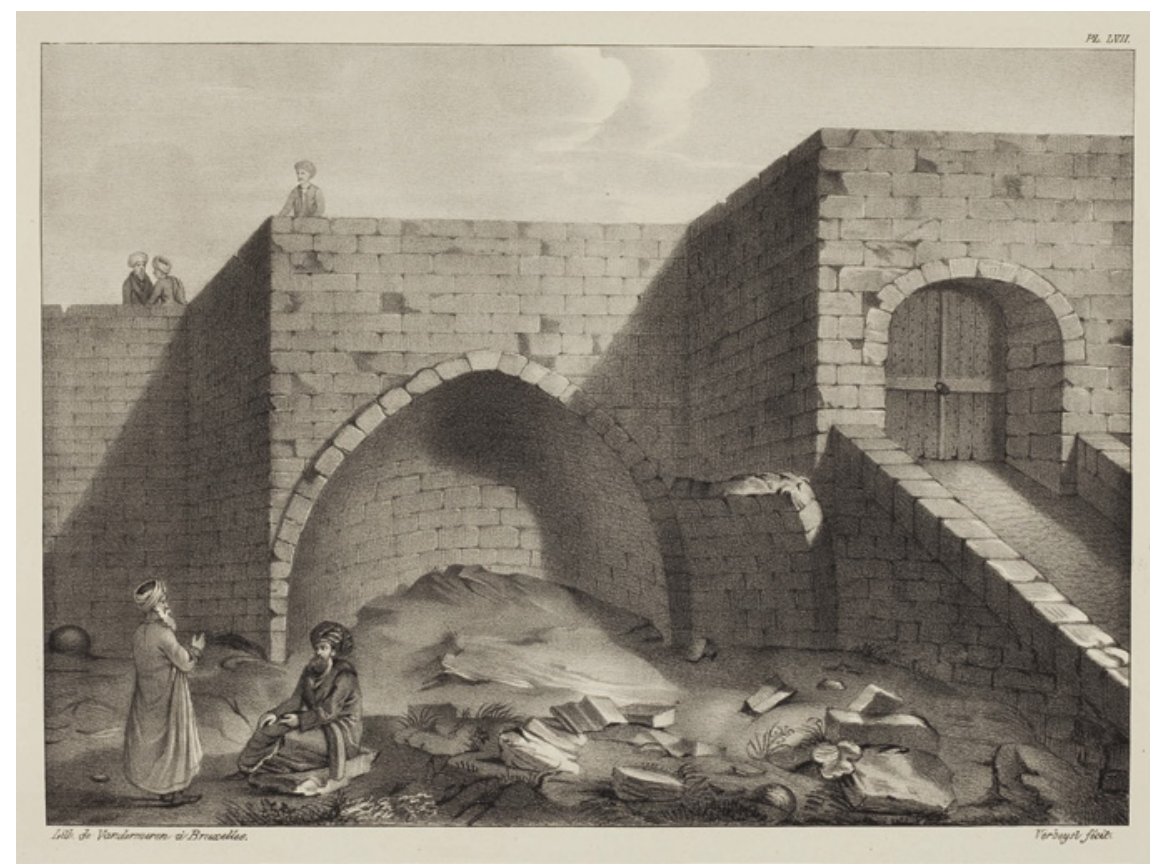

FIGURE 76 Unidentified church on Kisthiniou St., Rhodes, 1828, lithograph after P. J. Witdoeck

Falk from Fribourg and the Knight Melchior zur Gilgen from Lucerne were also buried at the site. ${ }^{157}$

As far as the identification of the church of Our Lady of Victory is concerned, it was Rottiers who first located it, with the help of a Franciscan friar, at the site of the present anonymous church in Kisthiniou St. (Fig. 76). ${ }^{158}$ However, in 1856 Guérin situated it at the northeastern end of the walls, an identification that remained prevalent in the following years (Fig. 55); in the meantime, the anonymous church in Kisthiniou St. had been covered by buildings. ${ }^{159}$

In 2004 an archaeological investigation brought to light the remains of the anonymous Greek church on Kisthiniou St. (Fig. 77 a). ${ }^{160}$ It is a single aisled construction $(16.5 \times 8$ meters $)$ with a pointed vault and an apse on the east side that appears semicircular on the interior and three-sided on the exterior, with

157 Schmid 1957c, 52-53; Bloesch 1929, 39.

158 Rottiers 1830, 351; Rottiers 1828, pl. $5^{2}$.

159 Guérin 1856, 141; Kollias 2007, 291-292.

16o Manoussou-Ntella and Ntellas 2008, 125-127. 


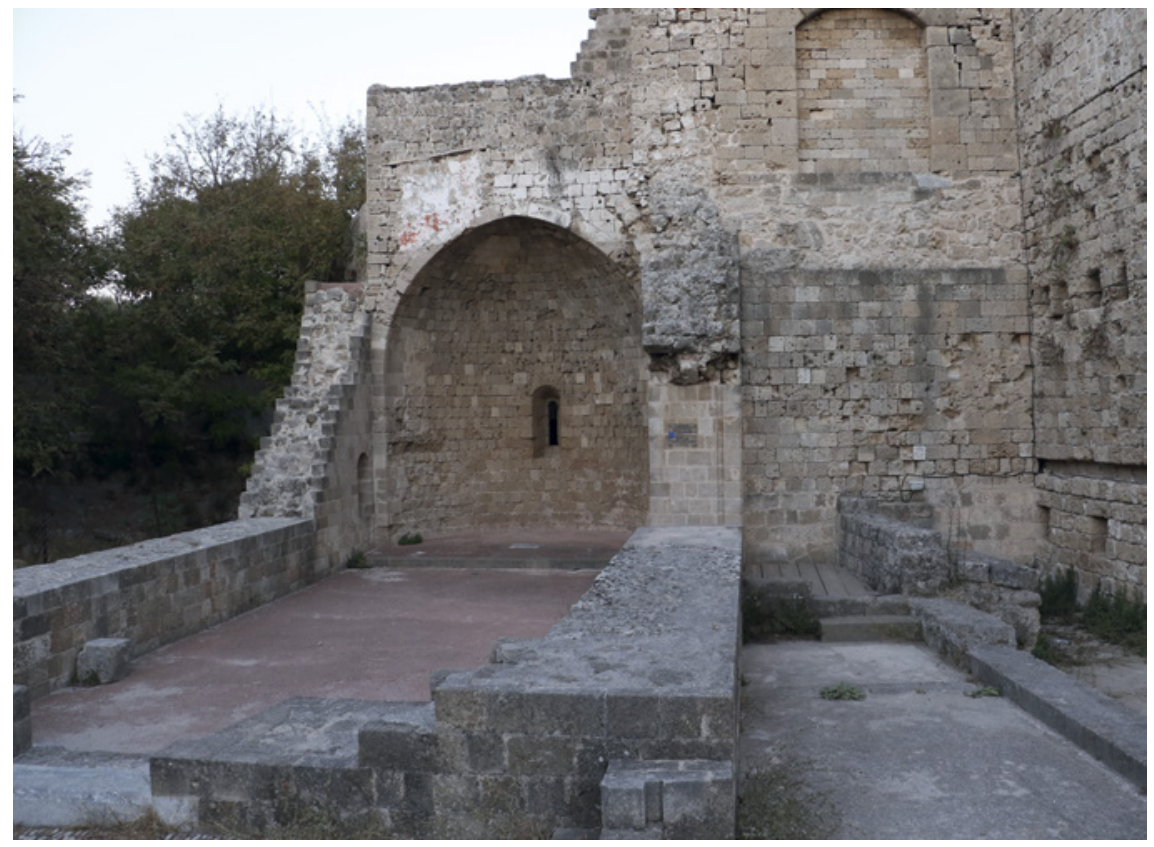

FIGURE 77A Unidentified complex in Kisthiniou St., Rhodes. Remains of the Greek church, view from the west

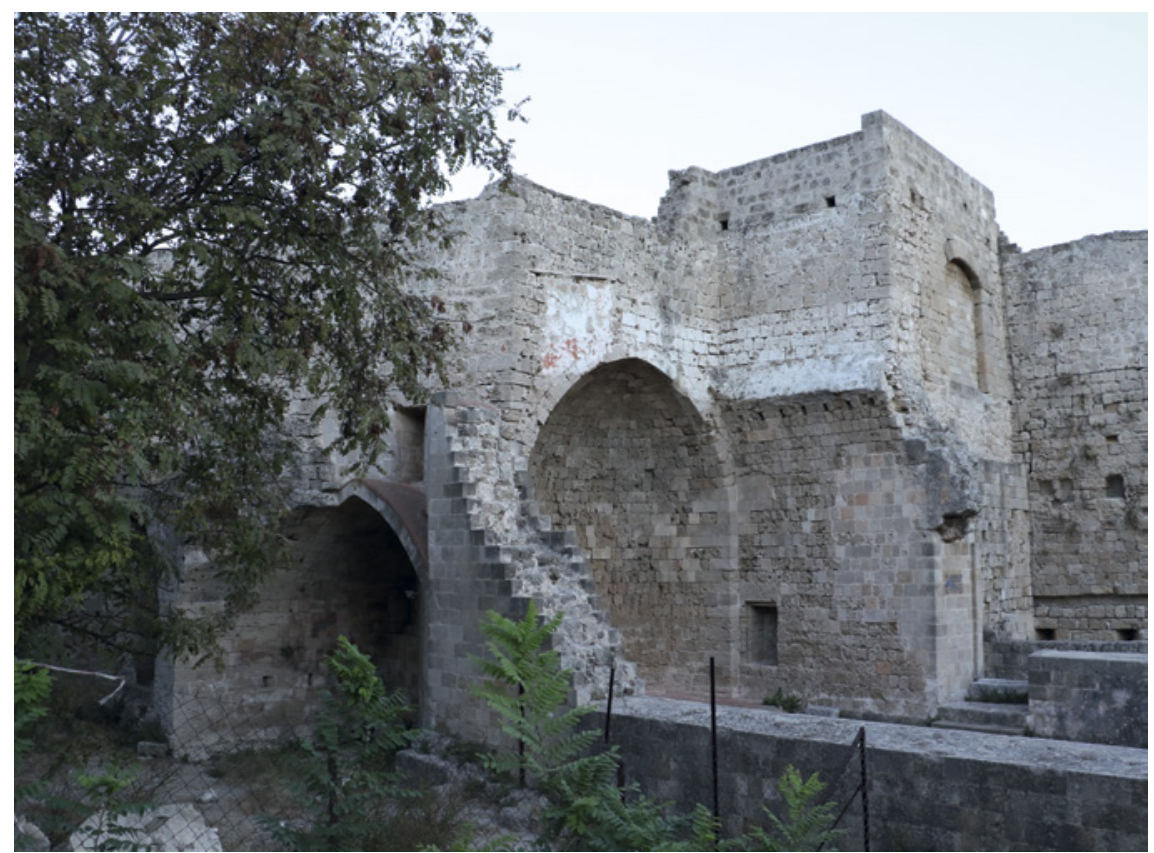

FIGURE 77B Unidentified complex in Kisthiniou St., Rhodes. Remains of the Greek church and the Gothic chapel, view from the northwest 
a quadrilateral dome. ${ }^{161}$ There were two entrances, one at the west and one at the south, and traces of wall paintings of the late 15th century to the early 16th were found. At the sanctuary, a marble slab that had been used as a base for the altar bore on its rear side the arms of the Order and of the Master Fluvià (1421-1437); it seemed clear that it must have been reused years after Fluvià's death. ${ }^{162}$ On the northern part there are traces of a medieval staircase leading to the walls; this may have been the one depicted in Caoursin's miniatures, which, however, do not depict the church. ${ }^{163}$

To the north of this building, a funerary chapel $(9.5 \times 7.5$ meters $)$ was revealed and excavated (Fig. 77b). It has a three-sided apse, and the floor is paved with terracotta tiles. Two marble tomb slabs were found: one belonging to Martino de Rossca, a Basque who died in 1505; and the second belonging to Johanna de Perier, a noblewoman from Brittany, who died on her way back from her pilgrimage to the Holy Land in $1493 .{ }^{164}$ Further burials where found in the area between the chapel and the Orthodox church, nine in total. ${ }^{165}$

The Gothic church to which this chapel belonged should lie to its north, but the pending expropriation of the site has delayed the excavation works. The aforementioned evidence, though, has led to the conclusion that this complex most possibly corresponds to Our Lady of Victory and St. Pantaleon (Figs. $78 \mathrm{a}, 78 \mathrm{~b}$ ). ${ }^{166}$ Many issues exist that cannot be resolved without extensive excavations. Archival evidence documents two chapels on the south side of the church, one dedicated to the Assumption of the Virgin and the other to St. Pantaleon, a setting that would be in line with the plan that has been worked out if not for their size, since St. Pantaleon is mentioned as the smaller one; moreover, there was a third chapel in another part of the building. ${ }^{167}$ Should the excavations also reveal the burial of Francesco Trivulzio, the identification would become certain.

\subsection{Cultic Phenomena}

The churches of Our Lady of Victory and St. Pantaleon are both mentioned by pilgrims in reference to the miraculous intervention of the Virgin that secured victory over the Ottomans. These sanctuaries ultimately served as the memorial site of the prodigious event and, consequently, of the Virgin's powers. In

\footnotetext{
161 Ibid.; Kollias 2007, 293-294.

162 Kollias 2007, 293-294.

163 Ibid.; Manoussou-Ntella and Ntellas 2018, 146.

164 Manoussou-Ntella and Ntellas 2008, 126; Kasdagli and Katsou 2007, 90-100.

165 Manoussou-Ntella and Ntellas 2008, 126-127.

166 Kollias 2007, 295; de Vaivre 2009b, 377-380; Manoussou-Ntella and Ntellas 2018, 143-148; Manoussou-Ntella and Ntellas 2019, 157-159.

167 Tsirpanlis 2012, 233.
} 


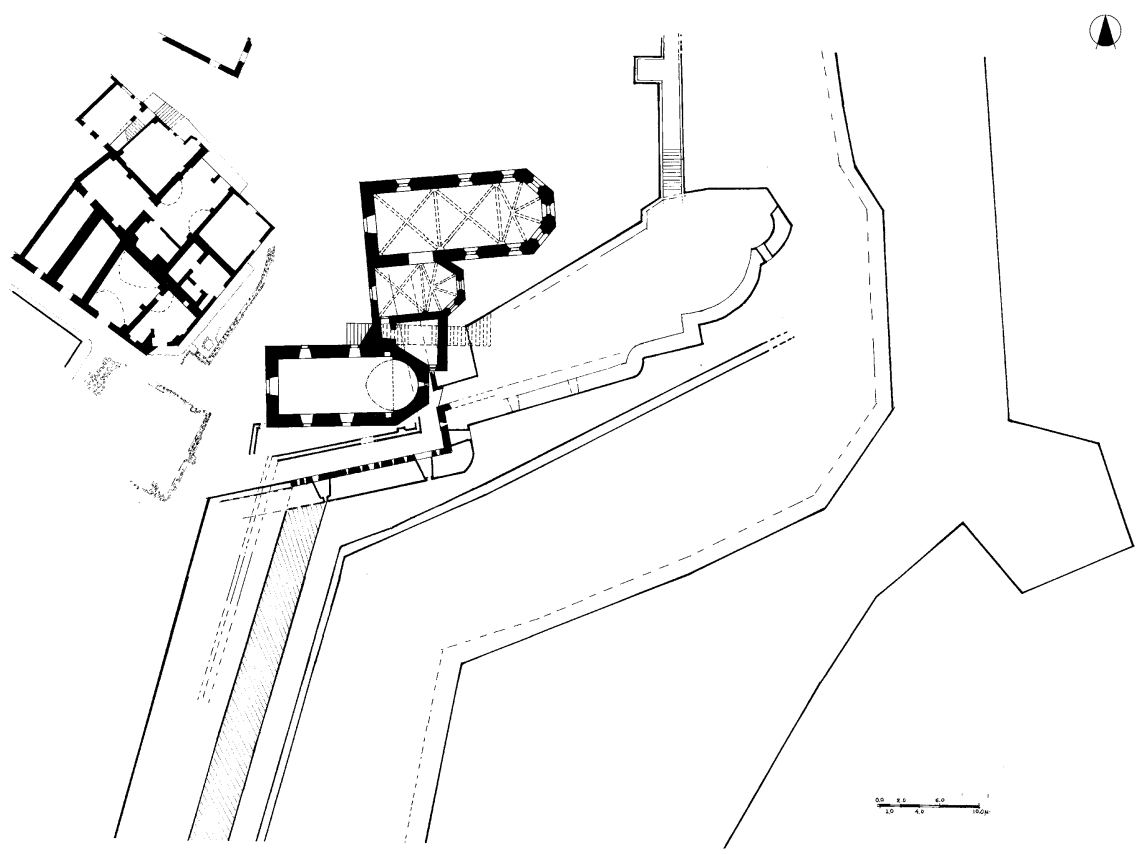

FIGURE 78A Unidentified complex on Kisthiniou St., Rhodes. Plan

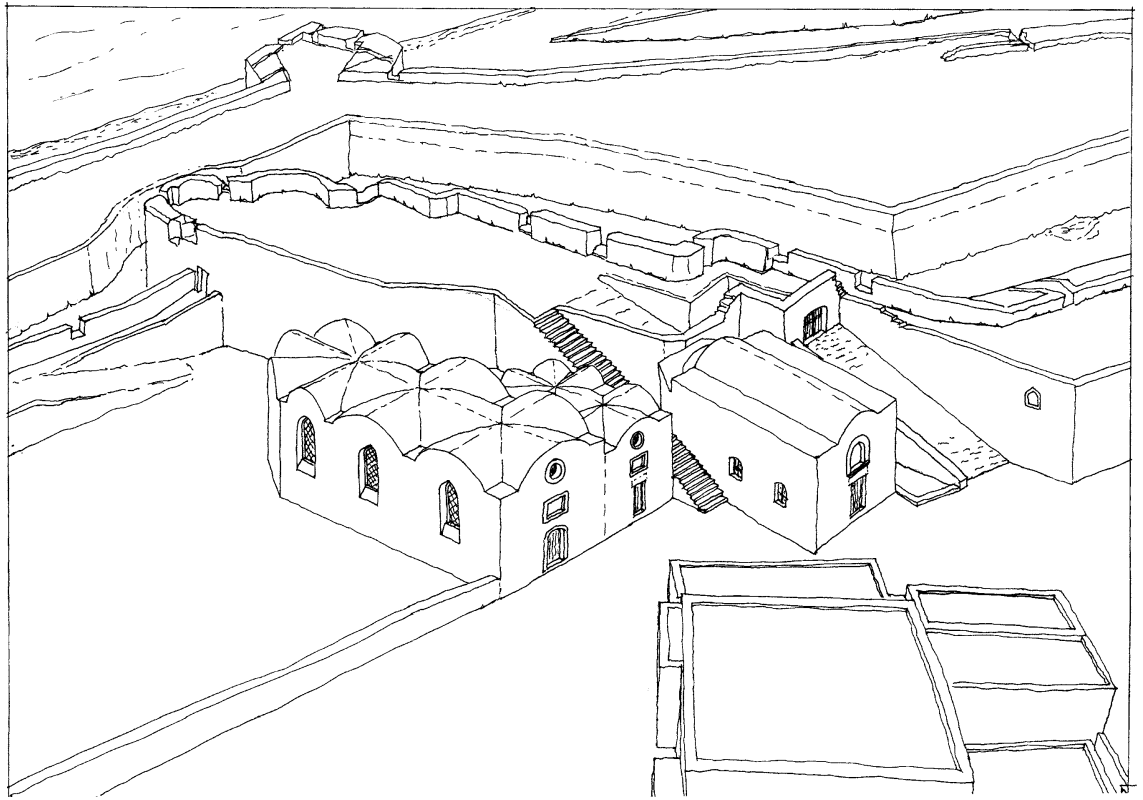

FIGURE 78B Unidentified complex on Kisthiniou St., Rhodes. Graphic reconstruction 
this way, the church of Our Lady of Victory constituted a material expression of Marian devotion that was foremost centered on the Virgin of Phileremos, an expression that, on this occasion, celebrated the Madonna as the shield of the city and the guarantor of victory. The church's donor, Master Aubusson, demonstrated his fervent devotion to the Virgin on numerous occasions, this being one of the most memorable ones. ${ }^{168}$

According to the German pilgrim Dietrich von Schachten (1491), there was a copy of the Holy Sepulchre at this church and not at the church of St. Catherine's hospice, as mentioned by Barthélemy de Salignac. ${ }^{169}$ As if two different testimonies were not enough, Jehan de Tournai (1488-1489) situates the copy at the Augustinian cloister. ${ }^{170}$ It is difficult to reach a conclusion. In the case of Jehan de Tournai, he admits not having seen the copy. Could it then be supposed that he was misinformed? Since no other evidence concerning such a construction is available, the only concrete information that arises is that such a setting existed at least in 1488. Again, it cannot be taken for granted that the pilgrims are referring to the same structure.

Hypothetically, the construction of a copy of the Holy Sepulchre at a Franciscan church would seem very befitting, due to the role of the friars as Custodians of the Holy Land and their part in the establishment of the Way of the Cross. ${ }^{171}$ Moreover, in 1497, the year that Master Aubusson granted Our Lady of Victory to the Franciscans, he also made a tribute to the Holy Sepulchre in Jerusalem: he began to subsidize the friars at the Holy Sepulchre annually, so that they would celebrate a service every week in favour of his longevity and his memory, after his death, as well as for the salvation of the Order. ${ }^{172}$ This fact, along with the prominent position of Our Lady of Victory on the axis of the eastern end of the central road coming from the port, which passed along

168 Enduring indications of his piety are found at Phileremos and Lindos, where his coats of arms are preserved in the churches dedicated to the Virgin. Apart from his commissions at Phileremos, he also secured the incomes for the priests of the Virgin of Lindos and the Virgin of Apollona, with the obligation, on their part, to perform a funeral service on the day of his death, to celebrate the mass every year on the anniversary of his death, and to pray for his soul on their feast days; see idem, 235. The church of the Holy Cross at Apollona has a silver revetment bearing the arms of Aubusson that is now covering a 17th-century icon of the Virgin with Child; Phillips 2013, 16-17.

169 Röhricht and Meisner 188ob, 184. The question of the existence of a copy of the Sepulchre and its connection with a possible Rhodian Way of the Cross has already been investigated above. The aim here is to deal with the contradictory sources concerning its location.

170 Blanchet-Broekaert and Péricard-Méa 2012, 182.

171 See note 63, p. 157 , and note 77 , p. 161, above.

172 Tsirpanlis 2012, 233-234. 
the complex of St. Catherine's hospice, supports Dietrich von Schachten's version. ${ }^{173}$

Another possible clue relating to a Rhodian copy of the Holy Sepulchre is the information that in 1493 Emery d'Amboise, while serving as the Prior of France, built an oratory at the Paris Temple in imitation of the Jerusalem Sepulchre. ${ }^{174}$ This information was delivered by Bosio, who adds that the royal family, the court, and the people of Paris frequented it, "being a curious and most devout thing."175 Could Emery d'Amboise have been inspired by the Rhodian copy or perhaps commissioned one at Rhodes too? Whatever the case, the Rhodian copy of the Holy Sepulchre would have been erected on the outskirts of the borgo, and its possible connection with a Way of the Cross would have transformed its site into a basic element of a topographical and evocative mimesis of Jerusalem. Its noteworthiness is attested by the distinct, although scant, references delivered by pilgrims.

A final piece of information concerning the cultic phenomena connected with Our Lady of Victory is the report from Ottheinrich, Pfalzgraf bei Rhein (1521), concerning the German captain Betz von Lichtenberg. He died during the decisive battle of 1480 at the breach in the Italian sector and was consequently buried in an unknown location. However, his body did not show signs of putrefaction; it was only when his corpse was transferred to his place of death, obviously at the recently built church, that it decomposed, a fact that inspired the attribution of saintly qualities to the captain. ${ }^{176}$

173 Manoussou-Ntella and Ntellas 2018, 146.

174 Bosio 163o, 512. See also Viollet-Le-Duc 1868, 14; Richard Krautheimer 1942, 10. It existed until the 18 th century.

175 Bosio 1630, 512: "come cosa curiosa, e molto divota."

176 Reichert 2005, 166-167. This story cannot but bring to mind the one concerning the soldier whose corpse finally decomposed when buried at St. Anthony; see p. 176 above. 